\title{
A high-resolution linkage map for comparative genome analysis and QTL fine mapping in Asian seabass, Lates calcarifer
}

Chun Ming Wang, Zhi Yi Bai, Xiao Ping He, Grace Lin, Jun Hong Xia, Fei Sun, Loong Chueng Lo, Felicia Feng, Ze Yuan Zhu and Gen Hua Yue*

\begin{abstract}
Background: High density linkage maps are essential for comparative analysis of synteny, fine mapping of quantitative trait loci (QTL), searching for candidate genes and facilitating genome sequence assembly. However, in most foodfish species, marker density is still low. We previously reported a first generation linkage map with 240 DNA markers and its application to preliminarily map QTL for growth traits in Asian seabass (Lates calcarifer). Here, we report a high-resolution linkage map with 790 microsatellites and SNPS, comparative analysis of synteny, finemapping of QTL and the identification of potential candidate genes for growth traits.

Results: A second generation linkage map of Asian seabass was developed with 790 microsatellite and SNP markers. The map spanned a genetic length of $2411.5 \mathrm{cM}$, with an average intermarker distance of $3.4 \mathrm{cM}$ or 1.1 Mb. This high density map allowed for comparison of the map with Tetraodon nigroviridis genome, which revealed 16 synteny regions between the two species. Moreover, by employing this map we refined QTL to regions of 1.4 and $0.2 \mathrm{cM}$ (or 400 and $50 \mathrm{~kb}$ ) in linkage groups 2 and 3 in a population containing 380 progeny; potential candidate genes for growth traits in QTL regions were further identified using comparative genome analysis, whose effects on growth traits were investigated. Interestingly, a QTL cluster at Lca371 underlying growth traits of Asian seabass showed similarity to the cathepsin D gene of human, which is related to cancer and Alzheimer's disease.

Conclusions: We constructed a high resolution linkage map, carried out comparative mapping, refined the positions of QTL, identified candidate genes for growth traits and analyzed their effects on growth. Our study developed a framework that will be indispensable for further identification of genes and analysis of molecular variation within the refined QTL to enhance understanding of the molecular basis of growth and speed up genetic improvement of growth performance, and it also provides critical resource for future genome sequence assembly and comparative genomics studies on the evolution of fish genomes.
\end{abstract}

\section{Background}

Most economically important traits are quantitative in nature and are determined by many genes and gene complex where are described as quantitative trait loci (QTL) [1]. Traditional methods of genetic improvement of quantitative traits have relied mainly on phenotype and pedigree information [1], which are easily influenced by environmental factors. Genetic markers have

\footnotetext{
* Correspondence: genhua@tll.org.sg

Molecular Population Genetics Group, Temasek Life Sciences Laboratory, Research Link, National University of Singapore, 117604 Singapore
}

made it possible to detect QTL that are significantly associated with traits [2], and made selection more effective. Genetic response can be improved by including the QTL in marker-assisted selection, which is a method of selection that makes use of phenotypic, genotypic and pedigree data [3].

Linkage maps are essential for mapping QTL [4]. In the past, genotyping of many markers was expensive, therefore, specific experimental designs were developed to reduce the impact of having fewer markers on statistical power [1]. More recently, however, high throughput methods have been developed to genotype markers

\section{Biomed Central}


such as microsatellites [5] and single nucleotide polymorphisms (SNP) [6], which have significantly reduced the cost. Linkage maps have been constructed for a number of foodfish species, such as salmon [7], rainbow trout [8,9], catfish [10], tilapia [11], grass carp [12], common carp [13], Asian seabass [14], European seabass [15] and Japanese flounder [16], gilthead seabream Sparus aurata [17-19] using RAPD, AFLP and microsatellites. Only in a few species, linkage maps solely based on codominant DNA markers (microsatellites and SNPs) were constructed. Most linkage maps in food fish species are not dense in comparison to these linkage maps in model fish species (e.g. Zebrafish [20]), chicken [21], live stock species (e.g. cattle [22,23], and pig [24]) and agronomic plant species (e.g. barley, soybean, grapevine [25-27]). QTL mapping in foodfish species is still in its infancy [6]. Only in a few species, such as Asian seabass [6], salmon [28], tilapia [29], Japanese flounder [30], rainbow trout [31] and European seabass [32], QTL for growth, meat quality, stress and disease resistance have been mapped in large genomic regions due to lack of a high resolution linkage map.

Linkage map with sequence-based markers is also a platform for comparative genome studies [33-36]. Recent comparative genome analyses based on genetic maps have already provided new insights into genome organization, evolution, and function across different organisms [12,33,35,37]. For example, comparison of the Caenorhabditis briggsae genetic map and the Caenorhabditis elegans genome reveals extensive conservation of chromosome organization and synteny despite a very long divergence time (80 to 110 million years), suggesting that natural selection operates at the level of chromosomal organization [37]. In another study, a genetic linkage map of the blind Mexican cavefish Astyanax mexicanus has been successfully applied to predict candidate quantitative trait genes relating to rib number and eye size by anchoring cavefish QTLs to the zebrafish genome [36]. BLAST searches of sequences of mapped markers of grass carp against the whole genome sequence of zebrafish revealed substantial macrosynteny relationship and extensive colinearity of markers between grass carp and zebrafish [12]. Identification of conserved synteny blocks across fish genomes would help to unravel ancestral genome architecture of fish and transfer genome information from model fish species to non-model foodfish species.

Asian seabass, Lates calcarifer, also called Barramundi, is one of the important foodfish species. This species has been cultured for more than 20 years in brackishwater ponds and in recent years in floating cages. The global annual production of Asian seabass was currently 400,000 metric tons according to FAO statistics [38]. In the past few years, we started a breeding program for
Asian seabass [39] and developed a number of genomic tools such as microsatellites [40-42], SNPs in genes [43], microRNA [44], a linkage map with 240 microsatellites [14], BAC and cDNA libraries $[43,45,46]$ and a BACbased physical map [44] to facilitate the selective breeding program. The linkage map has been used to map QTL for growth traits, and significant QTL for growth traits were mapped on linkage groups 2 and $3[39,47]$. However, due to the lack of markers in the QTL regions, it is impossible to map the QTL in smaller chromosomal regions. For fine mapping QTL, comparative analysis of synteny and searching for candidate genes in QTL region, a high-density linkage map is essential.

In this report we present a second generation linkage map of Asian seabass. The current updated version of the Asian seabass consensus linkage map is a considerable improvement compared with the previous version [14]. This linkage map allowed for carrying out comparative mapping of synteny between Asian seabass and Tetraodon nigroviridis, and enabled fine mapping of QTL for growth traits. In addition, we identified potential candidate genes in QTL for growth traits, and defined the phenotypic consequences of alternative candidate gene alleles.

\section{Results}

\section{Identification and genotyping of DNA markers}

A total of 4300 clones collected from libraries enriched for CA-, GA-, CAA- GACA- and GATA-microsatellites were sequenced in both directions. Two thousand and eight hundred clones contained microsatellites, yielding 1520 unique sequences. Among the 1520 sequences, 1280 had enough flanking regions for primer design. The first set of 920 primer pairs was used to amplify three parents from two reference families [14] for linkage mapping. Six hundreds and sixty primers were selected to genotype the two reference families including 96 individuals ( 3 parents and 93 offspring) due to the fact that these primers could amplify easily scorable PCR products. Among the 660 microsatellite markers, 280 were tetranucleotide microsatellites, which could be more easily scored than the di-nucleotide microsatellites (see Additional file 1). Ten SNPs in nine genes were genotyped by direct sequencing each individual in the two reference families.

\section{Linkage mapping}

Of 851 informative markers including 240 markers mapped in the first generation linkage map [14], 822 markers were assigned to linkage groups by two-point linkage analysis with LOD scores $>3.0$ using CRIMAP (Green et al. 1990). From this, a total of 790 (97\%) markers were mapped by multipoint linkage analysis. 
Among these markers, 53 initiated with LcaB were microsatellites isolated from BAC clones, $53 \mathrm{LcaE}$ from ESTs and 10 SNPs from genes (Additional file 1). Details about primer sequences, GenBank accession number, annealing temperature for PCR, PCR product size, and locations of the 790 markers are summarized in Additional file 1.

In most regions, the order of the markers on the new map was consistent with the previous map [14], although some regions were rearranged through incorporating the new markers and correcting old marker data. The current sex-averaged map spanned $2411.5 \mathrm{cM}$ of the Asian seabass genome (Figure 1, 2, 3, 4, 5, 6, 7, 8, $9,10,11,12)$. In the map, the intermarker distance was $3.0 \mathrm{cM}$. These 790 markers were located in 501 unique locations on the linkage map of the Asian seabass, with an average inter-location space of $4.8 \mathrm{cM}$ (Table 1).

Sex-specific maps were also constructed. The length of the male map was $2674.6 \mathrm{cM}$, with an average intermarker distance of $3.4 \mathrm{cM}$ whereas the female map was $2294.8 \mathrm{cM}$ long, with an average intermarker spacing of $2.9 \mathrm{cM}$. The male map comprised linkage groups ranging in length from 6.4 to $244.4 \mathrm{cM}$ while the female map contained linkage groups with a length ranging from 22.3 to $225.6 \mathrm{cM}$.

The distances between LcaB201 and LcaTe0215 at the end region of LG1, are 0 and $47.6 \mathrm{cM}$ on female and male map respectively, while the distances between Lca270 and LcaTe0382 in the near middle region of LG1, possible proximal to centromere region, are 39.2 and $0 \mathrm{cM}$ on female and male map respectively.
Similarly, in the end regions between LcaE142 and LcaB128 on LG2, Lca1508 and LcaTe0045 on LG3, LcaTe0194 and LcaE169 on LG5 and Lca114 and Lca454 on LG9, females had much lower recombination rates in telomeric regions than males. While in the near middle regions, possibly within regions proximal to the centromere between Lca359 and Lca137 on LG3, LcaB045 and Lca996 on LG9, Lca365 and LcaTe0191 on LG10, Lca1012 and Lca565 on LG17, Lca512 and Lca564 on LG23, LcaTe0485 and LcaTe0214 on LG24, recombination rates were much higher in females. It showed that females have much lower recombination rates in telomeric regions than males, while recombination rates were much higher in females within regions proximal to the centromere.

\section{Comparative genome analysis}

We used BLAT to identify homologs of the sequencebased markers of Lates calcarifer on the map. Sixty seven markers had a homolog and could be assigned to the chromosomes of Tetraodon nigroviridis. We compared the Lates calcarifer genetic map with assembled genome sequences of Tetraodon nigroviridis, identifying conserved synteny blocks in 16 of the 24 Lates calcarifer linkage groups, each of which contained 3 to 8 markers. The largest synteny block conserved between Lates calcarifer and Tetraodon nigroviridis was found in LG5 with 8 markers spanning $48 \mathrm{cM}$ in the Lates calcarifer linkage group and their best matches spanning $4 \mathrm{Mb}$ in chromosome 18 of the Tetraodon nigroviridis genome (Figure 13, 14, Additional file 2). Blasting sequences of

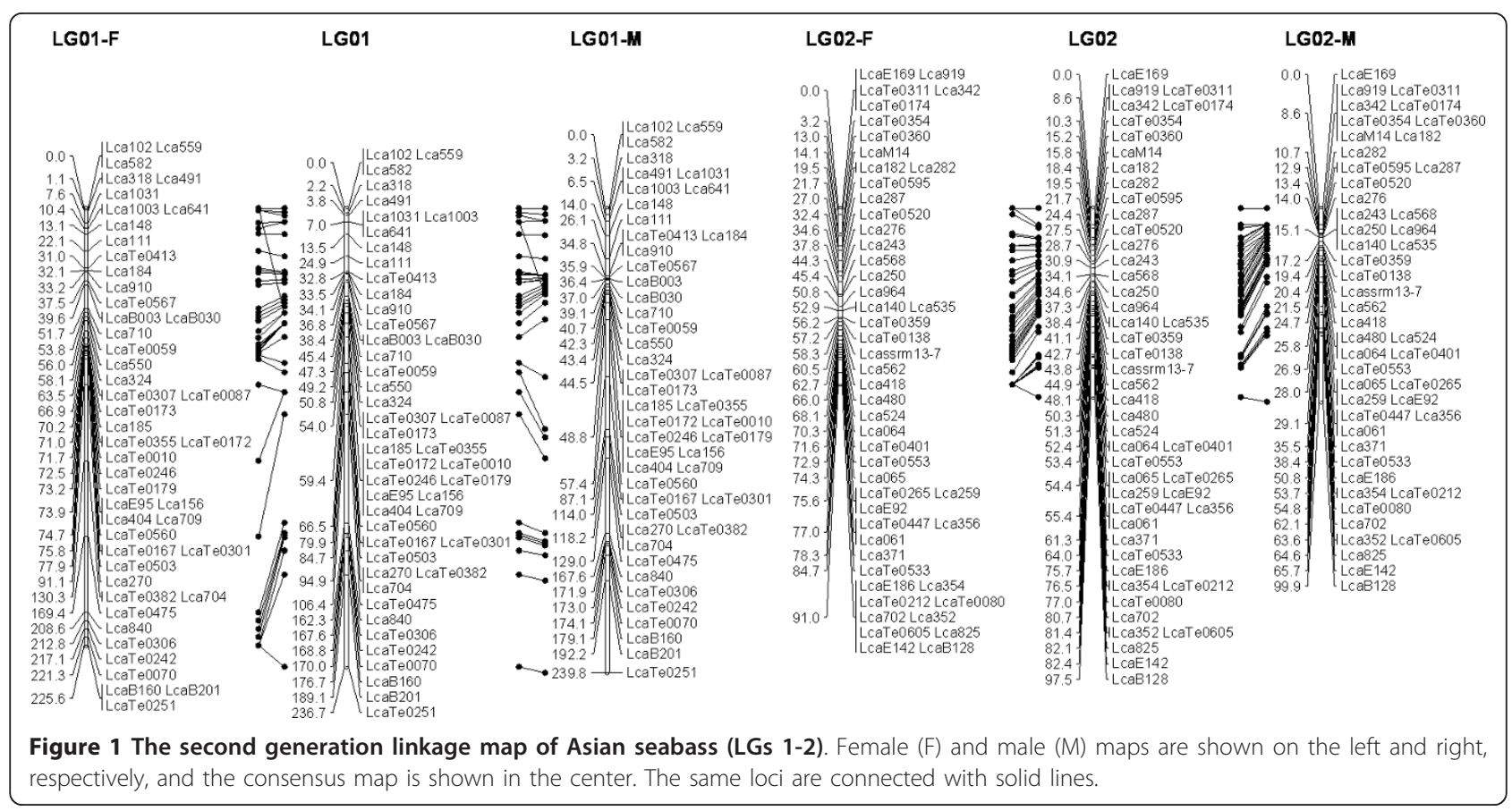




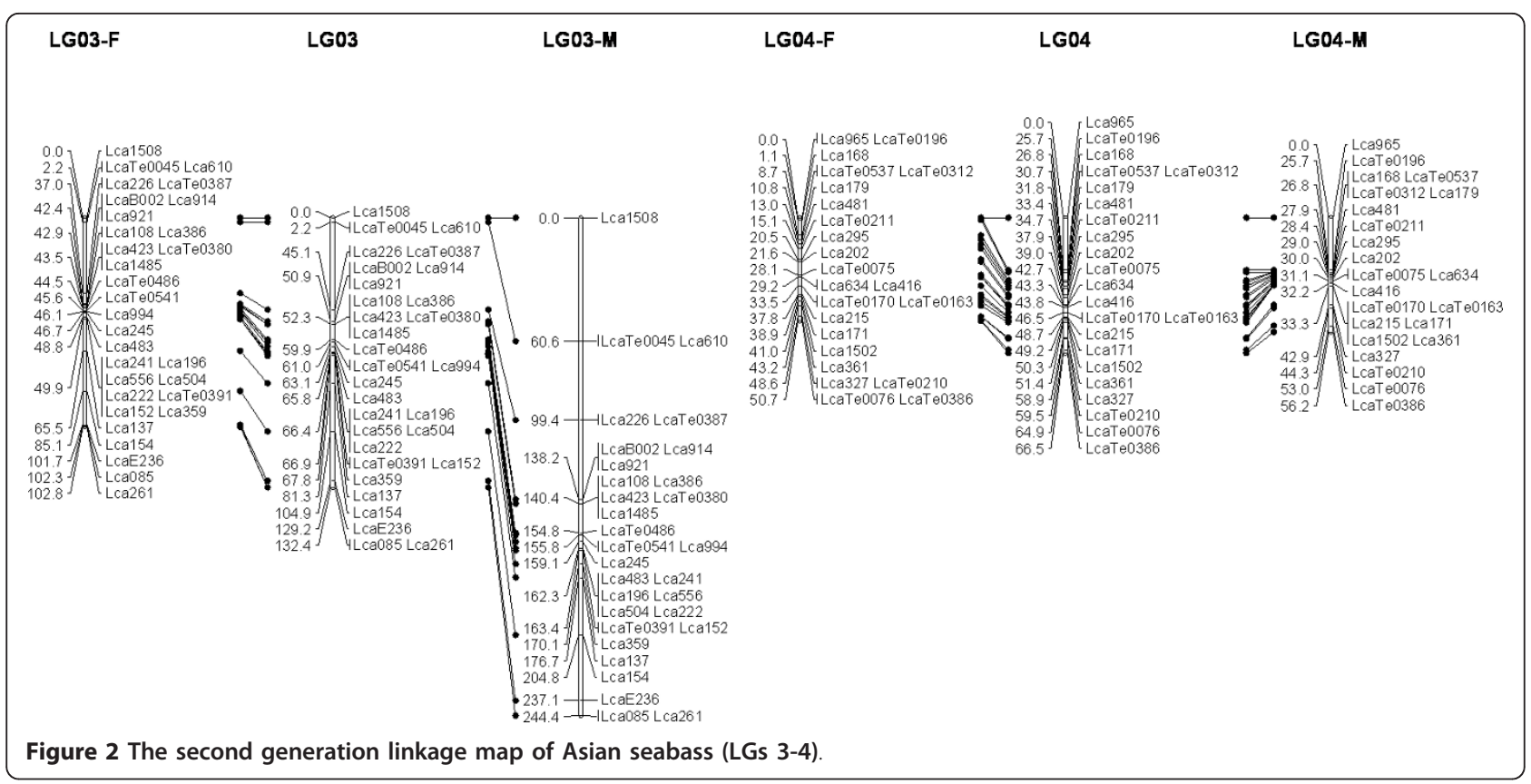

DNA markers of Asian seabass against whole genome sequences of zebrafish and medaka detected only very few conserved synteny (data not shown).

\section{Fine mapping QTL}

Additional 33 novel microsatellites located near QTL for growth traits on LGs 2 and 3 were selected and mapped with QTL panel containing 380 offspring. The linkage map was significantly improved for further QTL mapping as compared to the previous map by enhancing the density of markers for refinement of QTL positions (Figure 15). QTL analysis was carried out with genotype data of the markers and phenotypic data of all the progeny in the QTL mapping panel.

QTL affecting body weight, total length and standard length were identified on an experiment-wise scale. The experiment-wise LOD significance thresholds were 3.6,

\begin{tabular}{|c|c|c|c|c|c|c|c|c|c|c|c|}
\hline \multicolumn{2}{|c|}{ LG05-F } & \multicolumn{2}{|c|}{ LG05 } & \multicolumn{2}{|c|}{ LG05-M } & \multicolumn{2}{|c|}{ LG06-F } & \multicolumn{2}{|c|}{ LG06 } & \multicolumn{2}{|c|}{ LG06-M } \\
\hline $\begin{array}{c}0.0 \\
20.4 \\
23.6 \\
35.7 \\
44.4 \\
45.5 \\
46.2 \\
46.9 \\
47.7 \\
49.8 \\
50.9 \\
52.0 \\
52.5 \\
53.0 \\
54.1 \\
54.7 \\
55.2\end{array}$ & 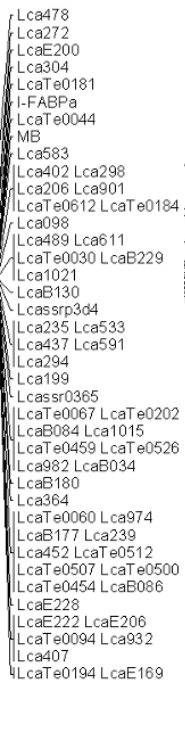 & \begin{tabular}{r}
0.0 \\
22.3 \\
24.6 \\
32.8 \\
41.0 \\
43.1 \\
47.9 \\
48.6 \\
50.2 \\
\hdashline \\
50.8 \\
52.9 \\
54.0 \\
54.5 \\
54.9 \\
55.1 \\
55.6 \\
56.2 \\
58.3 \\
60.5 \\
61.0 \\
61.5 \\
62.7 \\
63.8 \\
75.3 \\
75.9 \\
8 \\
80.0 \\
84.1 \\
95.8
\end{tabular} & 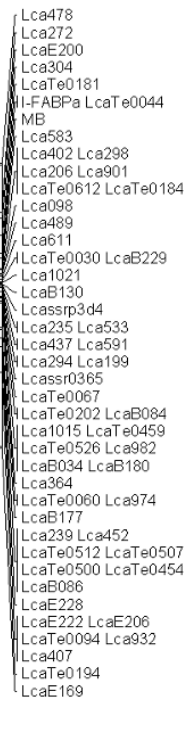 & $\begin{array}{r}0.0 \\
24.3 \\
27.1 \\
29.9 \\
37.5 \\
39.1 \\
40.7 \\
48.4 \\
49.5 \\
50.7 \\
53.9 \\
56.1 \\
57.1 \\
58.2 \\
59.3 \\
61.5 \\
64.7 \\
65.8 \\
66.9 \\
68.1 \\
69.4 \\
94.2 \\
95.3 \\
99.7 \\
104.1 \\
108.5 \\
112.8 \\
121.6 \\
126.0 \\
130.4 \\
134.8 \\
139.2 \\
143.6 \\
147.9 \\
182.3\end{array}$ & 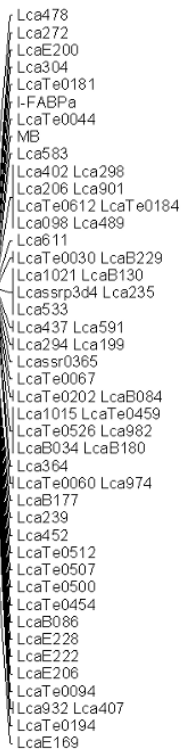 & $\begin{array}{l}0.0 \\
1.1 \\
4.3 \\
9.7 \\
9.9 \\
10.1 \\
10.4 \\
10.6 \\
10.8 \\
15.1 \\
17.3 \\
18.3 \\
24.1 \\
29.8 \\
34.1 \\
39.5 \\
42.7 \\
4.2 \\
45.7 \\
47.2 \\
52.6 \\
55.8 \\
59.0 \\
60.1\end{array}$ & 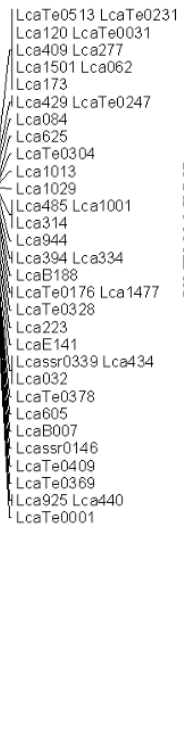 & 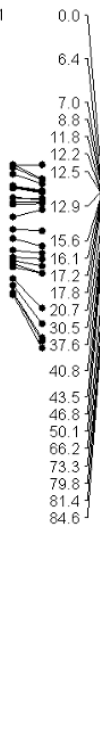 & 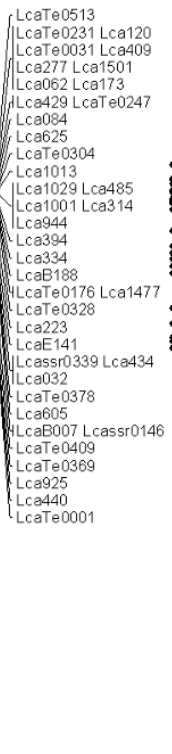 & $\begin{array}{c}0.0 \\
6.4 \\
7.0 \\
7.5 \\
7.2 \\
8.6 \\
9.7 \\
10.7 \\
14.0 \\
24.9 \\
34.7 \\
35.8 \\
37.9 \\
42.2 \\
46.6 \\
75.1 \\
86.1 \\
95.9 \\
100.3 \\
104.7\end{array}$ & 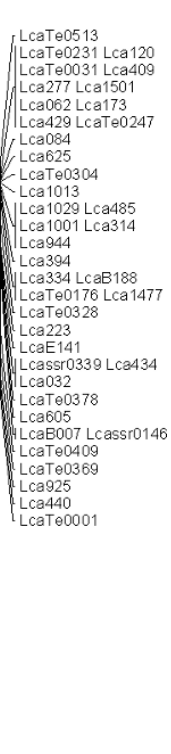 \\
\hline
\end{tabular}




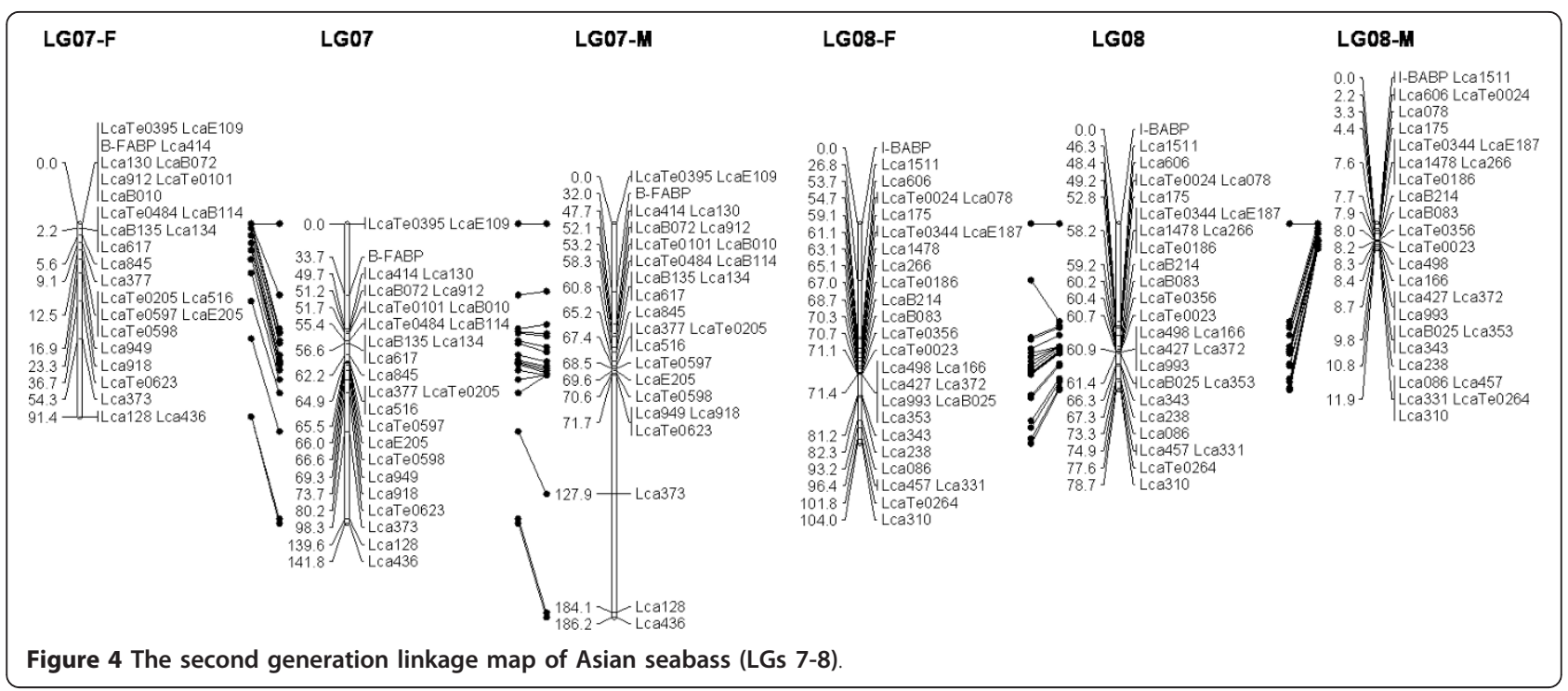

5.5 and 5.4 for body weight, total length and standard length, respectively, while the linkage-group-wise LOD significance thresholds varied from 2.3 to 5.5 (Table 2). Eleven QTL controlling body weight, total length and standard length were detected on LGs 2 and 3. Multiple QTL Model (MQM) mapping with initial QTL did not change the results.

The three QTL qBW2-a, qTL2-a and qSL2-a near the marker Lca287 showed high percentage of phenotypic variance explained (PVE) of 30.2, 53.1 and 53.8\%, respectively (Table 2). These QTL together with qBW2$\mathrm{b}$ are consistent to the previous QTL mapping results and their positions were finely refined as discussed later on.

Due to the more markers integrated in the QTL region, five QTL, i.e. qBW2-c, qBW2-d, qBW2-e, qTL2- c and qTL2-d, were newly detected. Although LOD values of qSL2-a and qSL2-c were not higher than the significant threshold, we still listed qSL2-a and qSL2-c to Table 2 as they showed obvious peaks and the LOD scores were very close to the threshold.

On LG2, the peaks of qBW2-a and qBW2-b were flanked by $L c a 182$ and Lca287 with distance $6.0 \mathrm{cM}$, and closely linked to Lca287 with a distance of $2 \mathrm{cM}$. Similarly, the peaks of the other QTL (qBW2-b, c, d and e) were located in a small region between flanking markers, with intervals of 6.1, 1.4, 0.6, 0.2 and $0.1 \mathrm{cM}$ respectively. On LG3, qBW3 was located in an interval of $0.1 \mathrm{cM}$ between $L c a 137$ and $L c a 159$. The LOD peaks were detected near the positions of markers Lca562, Lca371, LcaTe0359, Lca250 and Lca137 respectively (Table 2, Figure 15).

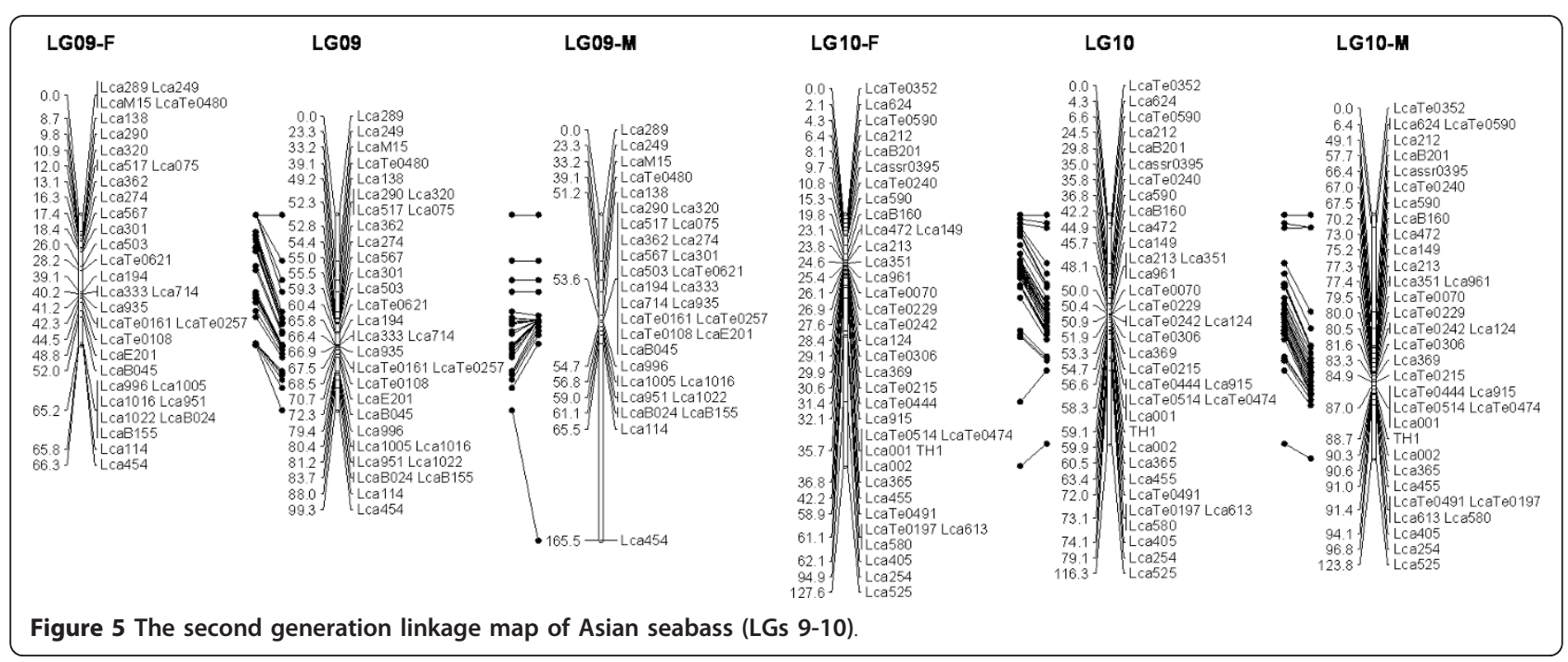




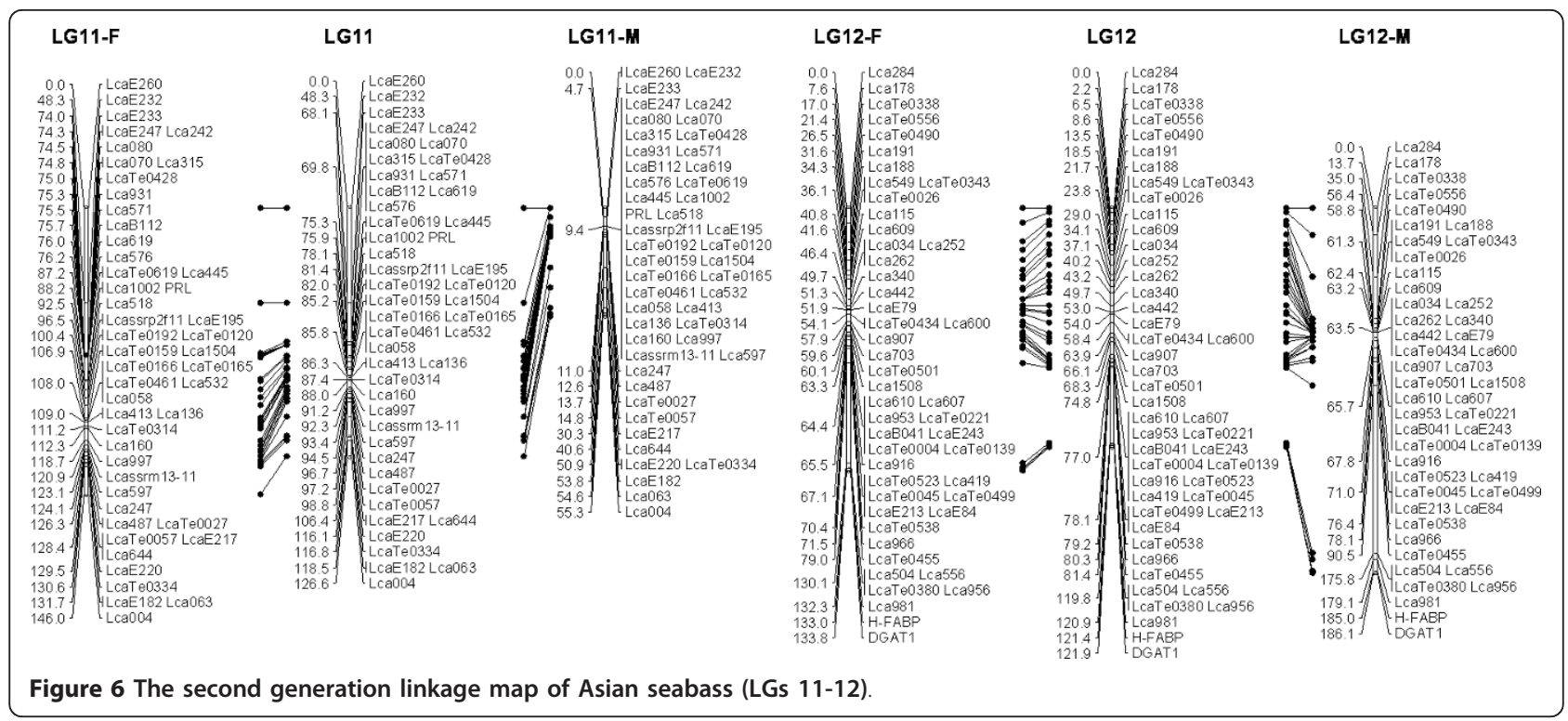

Potential candidate genes in refined QTL

As positions of some microsatellites collocating with QTL peaks, sequences of these DNA markers were blasted against the whole genome sequences of zebrafish and medaka. We detected some potential candidate genes for growth. Among these markers, a QTL cluster including qBW2-c, qTL2-c and qSL2-c were located in between markers Lca371 and Lca480 with distance of $1.4 \mathrm{cM}$, and QTL peaks collocated with the position of Lca371, whose sequence hit to genome sequences at 16.325 Mb on the chromosome 18 (Dr-18) in zebrafish, and at $2.311 \mathrm{Mb}$ chromosome $3(\mathrm{Ol}-3)$ in medaka
(Figure 16). When looking closely, we found that the sequence of the marker Lca371 showed very high similarity of the cathepsin D gene of medaka and zebrafish. We also found that the Lca371 showed similarity to the cathepsin D gene (Genbank accession nos: TC168775 and TC156330) of rainbow trout. Comparing the sequences of Lca371 to all 24,000 EST sequences generated by our group (unpublished data); we found that Lca371 was located in the cathepsin D gene of Asian seabass.

The peak of qBW2-e was located between the markers Lca568/LcaTe0265 and Lca250 with distance of $0.2 \mathrm{cM}$

\begin{tabular}{|c|c|c|c|c|c|c|c|c|c|c|c|}
\hline \multicolumn{2}{|c|}{ LG13-F } & \multicolumn{2}{|c|}{ LG13 } & \multicolumn{2}{|c|}{ LG13-M } & \multicolumn{2}{|c|}{ LG14-F } & \multicolumn{2}{|c|}{ LG14 } & \multicolumn{2}{|c|}{ LG14-M } \\
\hline $\begin{array}{c}0.0 \\
50.6 \\
52.7 \\
54.3 \\
56.0 \\
65.8 \\
66.9 \\
70.1 \\
72.2 \\
73.3 \\
75.5 \\
77.6 \\
79.8 \\
84.1 \\
87.3 \\
89.5 \\
90.6 \\
91.6 \\
93.8 \\
100.3 \\
101.3 \\
105.7\end{array}$ & 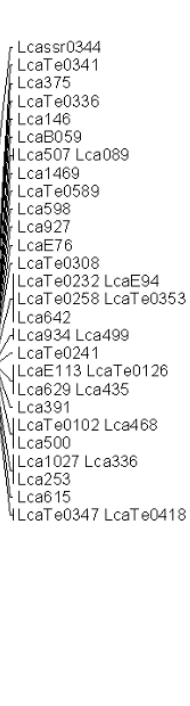 & $\begin{array}{r}0.0 \\
61.1 \\
63.3 \\
64.6 \\
66.6 \\
73.2 \\
73.9 \\
76.0 \\
77.5 \\
78.2 \\
79.6 \\
81.1 \\
83.2 \\
86.8 \\
89.0 \\
90.4 \\
91.1 \\
91.8 \\
92.9 \\
93.5 \\
101.0 \\
113.7 \\
128.7 \\
129.8\end{array}$ & $\left\{\begin{array}{l}\text { Lcassr0344 } \\
\text { LcaTe0341 } \\
\text { Lca375 } \\
\text { LcaTe0336 } \\
\text { Lca146 } \\
\text { LcaB059 } \\
\text { Lca507 Lca089 } \\
\text { Lca1469 } \\
\text { LcaTe0589 } \\
\text { Lca598 } \\
\text { Lca927 } \\
\text { LcaE76 } \\
\text { LcaTe0308 } \\
\text { LcaTe0232 LcaE94 } \\
\text { LcaTe0258 LcaTe0353 } \\
\text { Lca642 } \\
\text { Lca934 Lca499 } \\
\text { Lca3T0241 } \\
\text { LcaE113 LcaTe0126 } \\
\text { Lca629 Lca435 } \\
\text { Lca391 } \\
\text { LcaTe0102 Lca468 } \\
\text { Lca500 } \\
\text { Lca1027 Lca336 } \\
\text { Lca253 Lca } \\
\text { Lca615 } \\
\text { LcaTe0347 } \\
\text { LcaTe0418 }\end{array}\right.$ & {$\left[\begin{array}{c}0.0 \\
44.2 \\
88.4 \\
132.7 \\
134.8 \\
136.9 \\
\\
139.1 \\
\\
140.1 \\
142.3 \\
144.5 \\
175.9 \\
203.0 \\
205.1\end{array}\right]$} & $\begin{array}{l}\text { Lcassr0344 } \\
\\
\text { - LcaTe0341 } \\
\text { Lca375 } \\
\text { LcaTe0336 } \\
\text { Lca146 LcaB059 } \\
\text { Lca507 Lca089 } \\
\text { Lca1469 LcaTe0589 } \\
\text { Lca598 Lca927 } \\
\text { LcaE76 } \\
\text { LcaTe0308 } \\
\text { LcaTe0232 LcaE94 } \\
\text { LcaTe0258 LcaTe0353 } \\
\text { Lca642 Lca934 } \\
\text { Lca499 LcaTe0241 } \\
\text { LcaE113 LcaTe0126 } \\
\text { Lca629 Lca435 } \\
\text { Lca391 LcaTe0102 } \\
\text { Lca468 } \\
\text { Lca500 } \\
\text { Lca1027 } \\
\text { Lca336 } \\
\text { Lca253 } \\
\text { Lca615 } \\
\text { LcaTe0347 } \\
\text { LcaTe0418 }\end{array}$ & $\left.\begin{array}{c}0.0 \\
1.4 \\
3.6 \\
5.7 \\
15.5 \\
18.2 \\
20.8 \\
23.4 \\
26.0 \\
28.7 \\
29.7 \\
30.4 \\
31.1 \\
31.7 \\
32.4 \\
33.1 \\
35.6 \\
38.2 \\
40.7 \\
42.6 \\
46.1 \\
47.2\end{array}\right]$ & 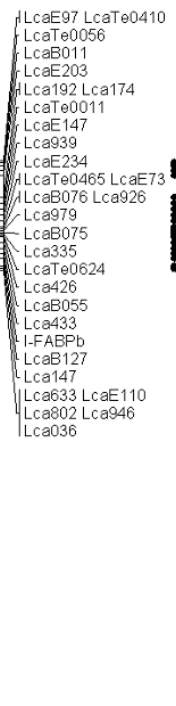 & $\left.\begin{array}{r}0.0 \\
3.4 \\
4.7 \\
6.9 \\
8.2 \\
14.0 \\
21.7 \\
25.6 \\
26.9 \\
37.3 \\
37.8 \\
38.2 \\
38.7 \\
39.1 \\
39.8 \\
41.6 \\
41.7 \\
44.8 \\
50.8 \\
53.0 \\
60.3 \\
72.4 \\
75.1\end{array}\right]$ & 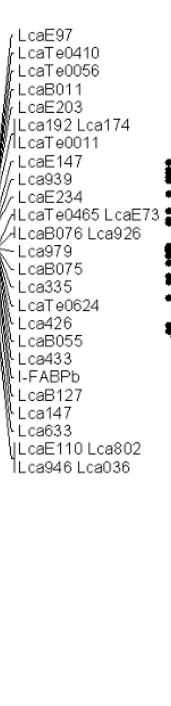 & $\left.\begin{array}{r}0.0 \\
2.4 \\
4.8 \\
6.9 \\
8.3 \\
9.1 \\
19.6 \\
24.9 \\
27.2 \\
34.5 \\
41.9 \\
42.3 \\
42.7 \\
43.1 \\
44.0 \\
45.5 \\
46.2 \\
48.6 \\
51.9 \\
55.2 \\
66.5 \\
101.7 \\
108.8\end{array}\right]$ & 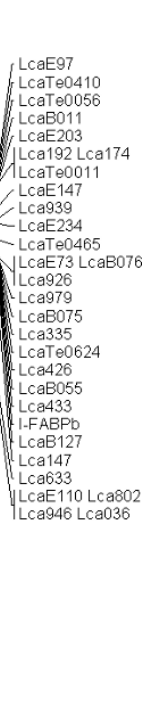 \\
\hline
\end{tabular}




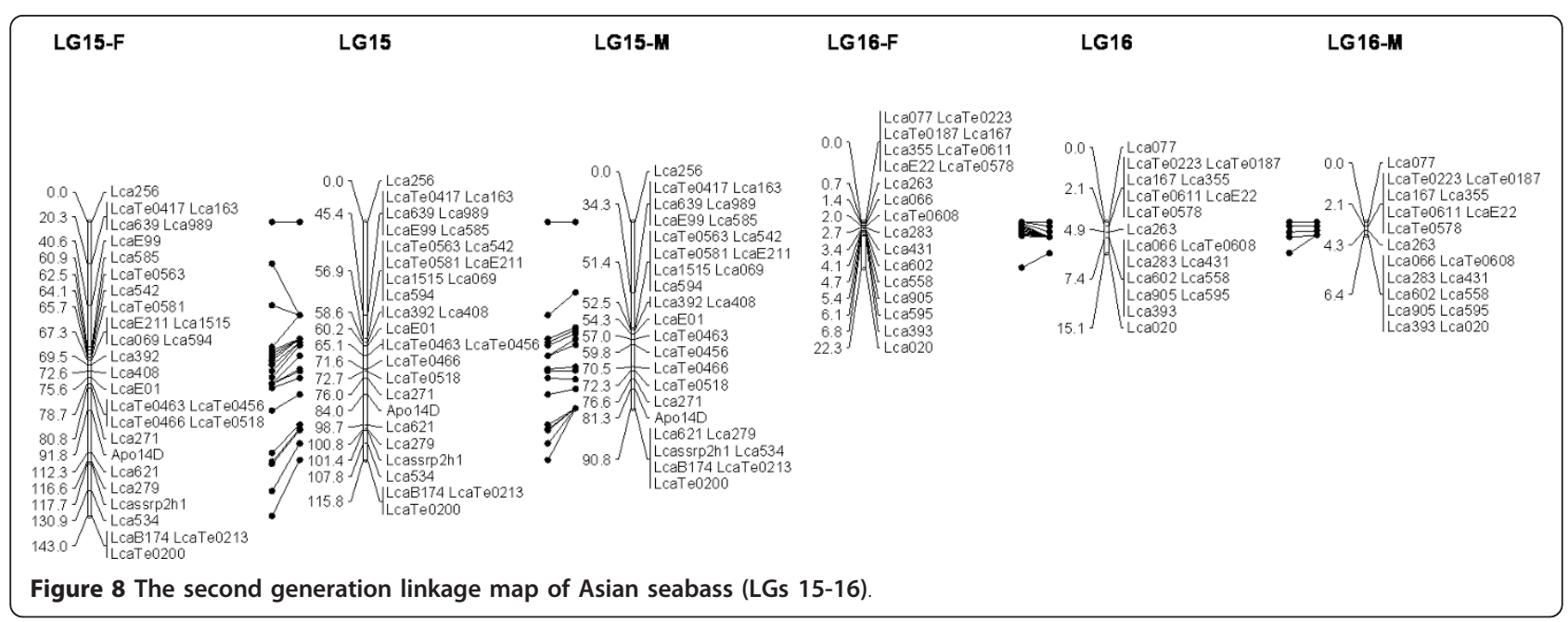

(Figure 16). The sequence of the marker Lca568 hit to genome sequences at $29.898 \mathrm{Mb}$ on the chromosome 3 (Ol-3) in medaka, and some of the sequences of the marker Lca568 showed very high similarity of the KCTD15 gene of medaka. The sequences of LcaTe0265 hit to genome sequences at $35.626 \mathrm{Mb}$ on the chromosome 19 (Dr-19) in zebrafish, and some of the sequences of the marker LcaTe0265 showed very high similarity of the $c s m d 2$ gene of zebrafish.

For Lca562, LcaTe0359 and Lca137, there were no hits to genes in medaka and zebrafish genomes.

\section{Effects of gene allele substitution}

A two-way ANOVA was performed on the 380 progeny using four allelic combinations ( $\mathrm{m} 1 \mathrm{f} 1, \mathrm{~m} 1 \mathrm{f} 2, \mathrm{~m} 2 \mathrm{f} 1$ and $\mathrm{m} 2 \mathrm{f} 2$ ) from markers in the three candidate genes of cathepsin D, KCTD15 and csmd2 in order to investigate associations between traits and genotypes of these genes. The phenotype values of each allelic combination of these three genes are listed in Table 2 and Figure 17.
Significant differences of phenotype means among different allelic combinations were identified, revealing the effects of alternate gene alleles inherited from the parents. Progeny with m2f2 genotype at the marker Lca371 located in cathepsin $\mathrm{D}$, showed the highest phenotype values. Similarly, progeny with m1f2 genotype at the marker Lca568 located in KCTD15 and LcaTe0265 in $\operatorname{csm} d 2$, showed the highest phenotype values. These results suggested the effect of these genes on growth related traits.

\section{Discussion}

Map density and recombination rate

The linkage map presented in this paper represents one of the most dense linkage maps based on microsatellites and SNPs for foodfish species. This second generation linkage map of Asian seabass contained 3.3 times as many sequence-based co-dominant loci as did the previous linkage map [14], and more sequence-based codominant markers than the linkage maps of major

\begin{tabular}{|c|c|c|c|c|c|}
\hline LG17-F & LG17 & LG17-M & LG18-F & LG18 & LG18-M \\
\hline 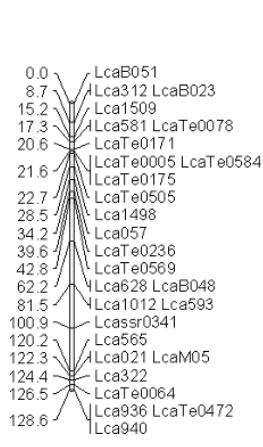 & 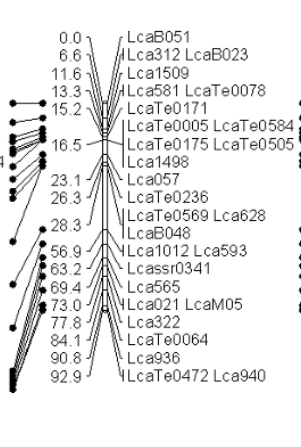 & 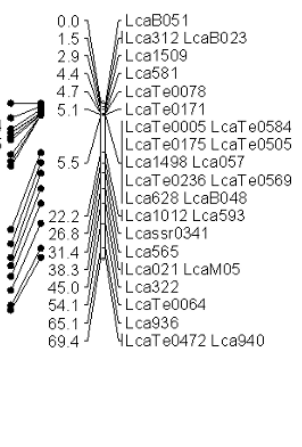 & 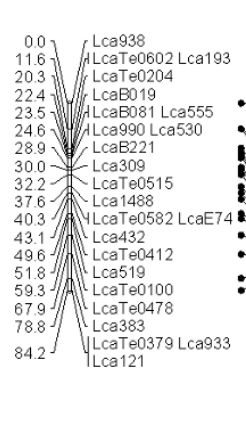 & 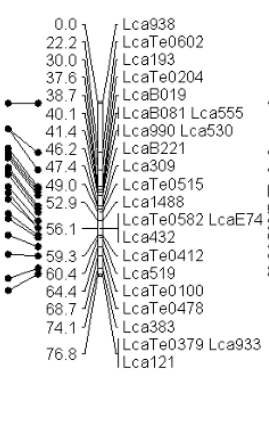 & 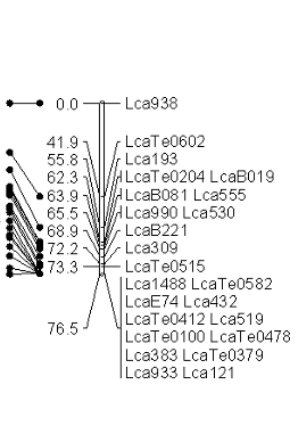 \\
\hline \multicolumn{6}{|c|}{ Figure 9 The second generation linkage map of Asian seabass (LGs 17-18). } \\
\hline
\end{tabular}




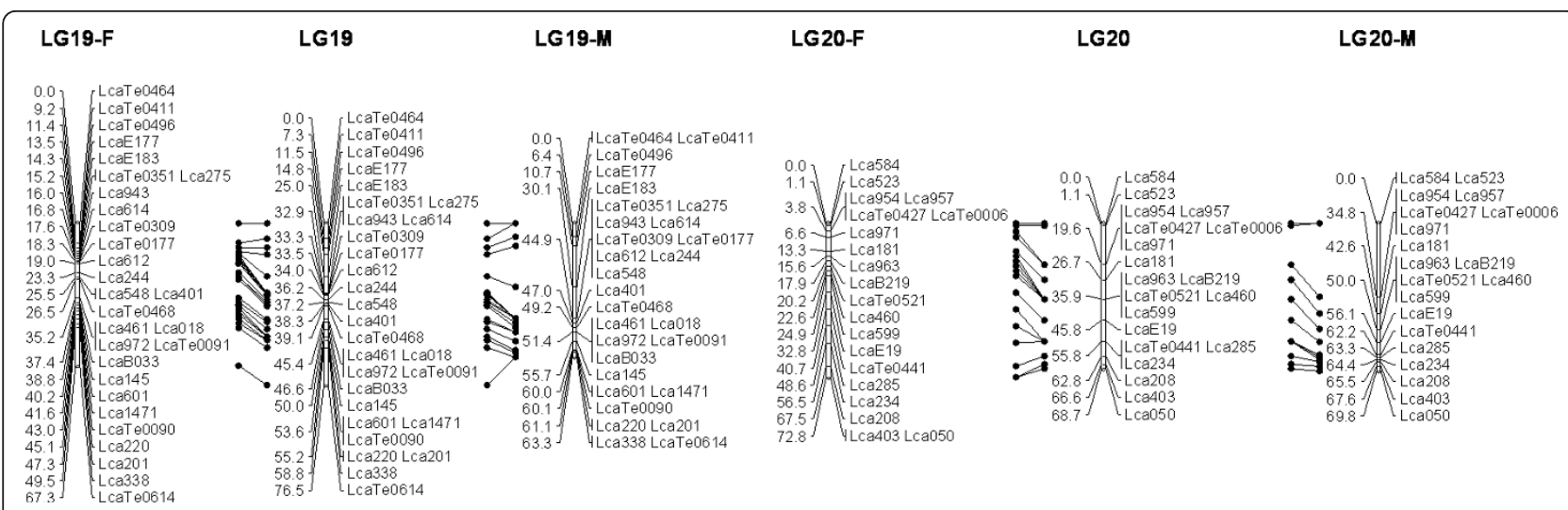

Figure 10 The second generation linkage map of Asian seabass (LGs 19-20).

foodfish species, such as salmon [7], tilapia [11], common carp [13], grass carp [12], Japanese flounder [16], catfish [10] and European seabass [15]. However, in comparison to the linkage maps of model fish species (e.g. zebrafish [20]), livestock (e.g. cattle [22,23], pig [24]), chicken [21]) and agronomical plant species (e.g. rice, barley, soybean, grapevine, [25-27,48], the marker density of the Asian seabass linkage map is still lower. This is mainly because the whole genome sequence and large number of SNPs in Asian seabass are still not available. Fortunately, sequencing the whole genome of Asian seabass is in agenda. The third generation of linkage map could be based on large number of SNPs. The current Asian seabass map spanned $2411.5 \mathrm{cM}$, and it is estimated to span much more of the Asian seabass genome in comparison with the previous linkage groups [14]. It had a resolution of $3.4 \mathrm{cM}$, which is sufficient for fine mapping QTL for future marker-assisted selection.

The average recombination rate across all linkage groups is approximately $3.4 \mathrm{cM} / \mathrm{Mb}$ in Asian seabass, which is higher than that in zebrafish $(1.35 \mathrm{cM} / \mathrm{Mb})$ [20], catfish (1.65 cM/Mb) [10], tilapia $(1.3 \mathrm{cM} / \mathrm{Mb})$ [11], grass carp $(1.2 \mathrm{cM} / \mathrm{Mb})$ [12], human $(1.20 \mathrm{cM} /$ $\mathrm{Mb})$, mouse (0.5 cM/Mb) [49] and lower than the plant Arabidopsis thaliana $(5 \mathrm{cM} / \mathrm{Mb}$; calculated based on data from The Arabidopsis Information Resource website). Based on the genome size of $700 \mathrm{Mb}[14,50]$ we estimated the average intermarker distance to be approximately $0.88 \mathrm{Mb}$ in the new linkage map which consisting 790 markers. This suggests that QTL, if identified, can be narrowed down to rather small genomic regions. The enhanced map will be invaluable not only for QTL and gene mapping but also for comparative

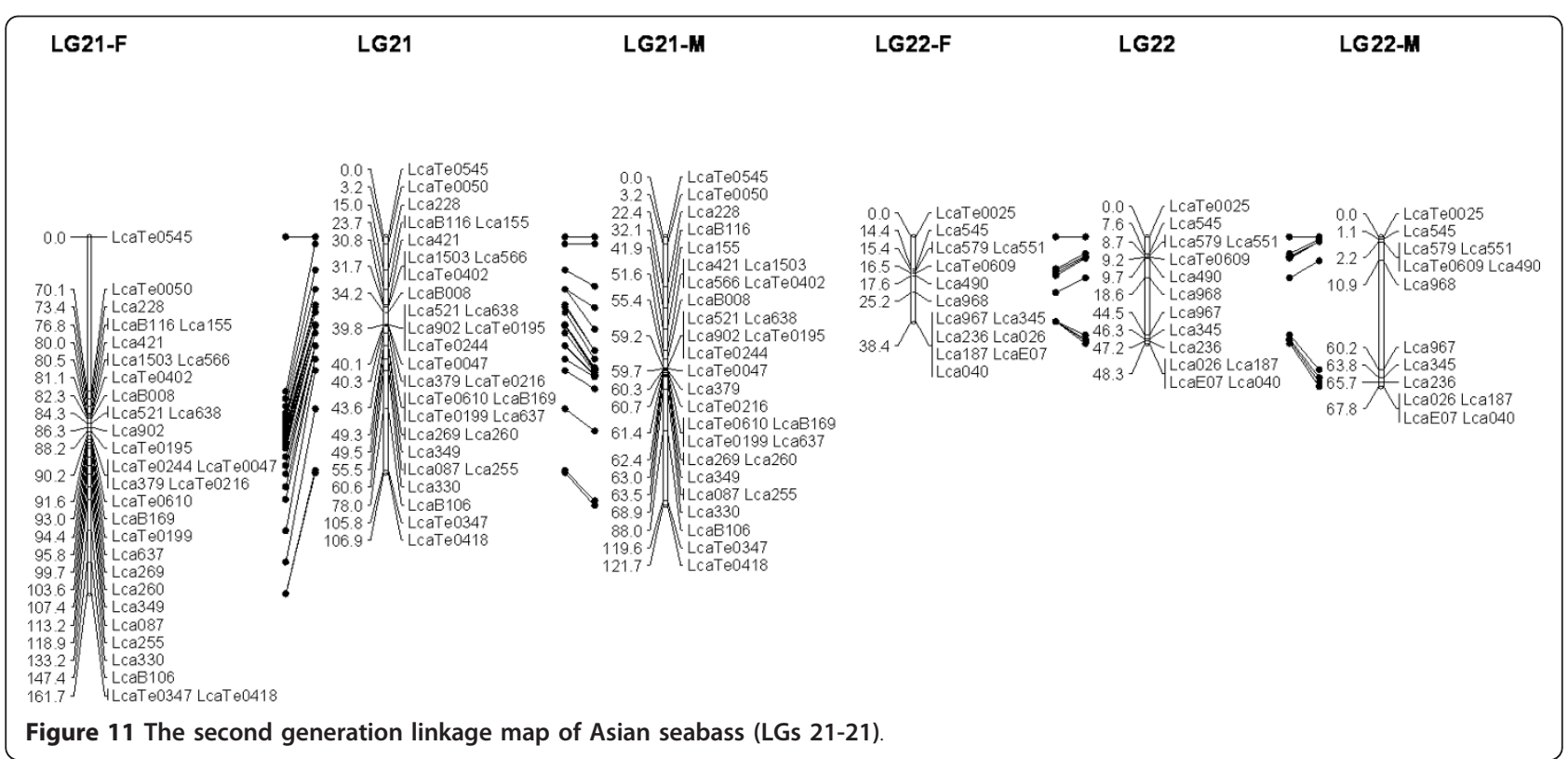




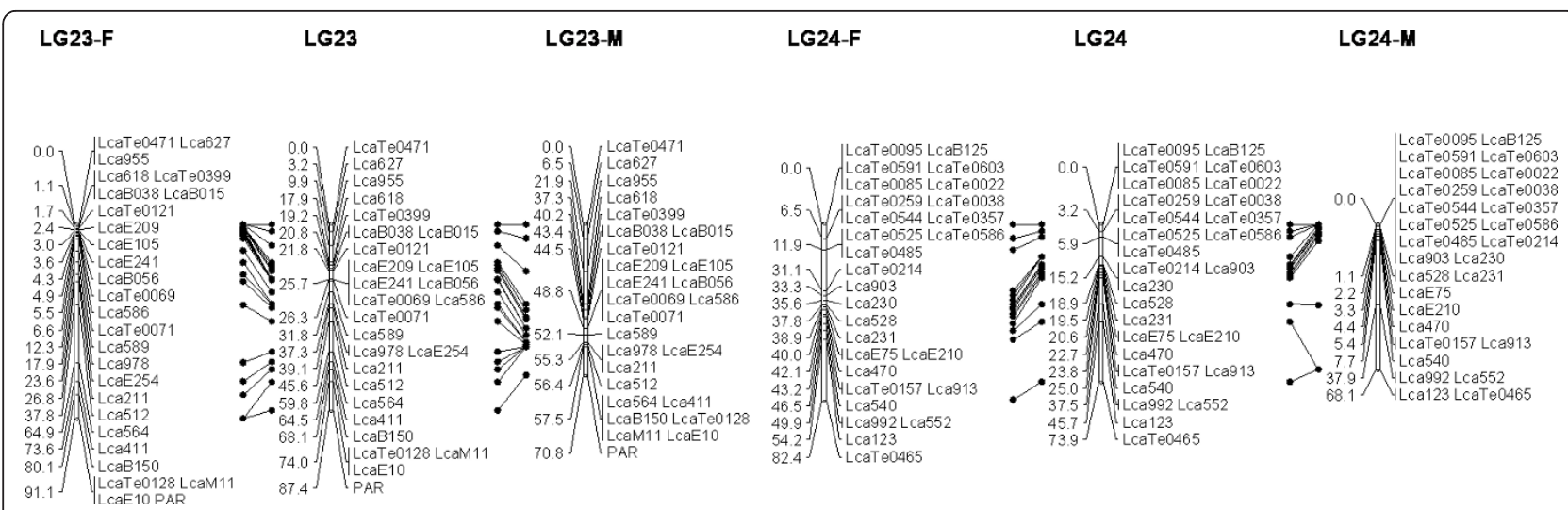

Figure 12 The second generation linkage map of Asian seabass (LGs 23-24).

genome analysis and assembling the Asian seabass genome once the whole genome sequencing available.

\section{Sex-specific patterns of recombination}

Different recombination rates between the sexes have been reported in mammals [8] and other fish species $[15,17,51]$ with female map distances usually greater than those in male maps $[8,52]$. In Japanese flounder, the recombination rate was unusually higher in males (7.4 times) compared to females [16]. Different to the previous map [14], the overall sizes of the male and female maps are comparable (female: $2294.0 \mathrm{cM}$; male: $2674.6 \mathrm{cM})$. Females had much lower recombination rates in telomeric regions than males, while recombination rates were much higher in females within regions proximal to the centromere. Females have much lower

Table 1 Summary of the second generation linkage group of Asian seabass

\begin{tabular}{|c|c|c|c|c|c|c|c|}
\hline \multirow[t]{2}{*}{ LG } & \multirow[t]{2}{*}{ No. of Markers } & \multicolumn{2}{|c|}{ Sex averaged } & \multicolumn{2}{|c|}{ Female } & \multicolumn{2}{|r|}{ Male } \\
\hline & & $\mathrm{cM}$ & $\mathrm{cM} /$ marker & $\mathrm{cM}$ & $\mathrm{cM} /$ marker & $\mathrm{cM}$ & $\mathrm{cM} /$ marker \\
\hline 1 & 48 & 236.7 & 4.9 & 225.6 & 4.7 & 239.8 & 5.0 \\
\hline 2 & 49 & 97.5 & 2.0 & 91.0 & 1.9 & 99.9 & 2.0 \\
\hline 3 & 31 & 132.4 & 4.3 & 102.8 & 3.3 & 244.4 & 7.9 \\
\hline 4 & 23 & 66.5 & 2.9 & 50.7 & 2.2 & 56.2 & 2.4 \\
\hline 5 & 58 & 130.1 & 2.2 & 62.7 & 1.1 & 182.3 & 3.1 \\
\hline 6 & 40 & 84.6 & 2.1 & 60.1 & 1.5 & 104.7 & 2.6 \\
\hline 7 & 27 & 141.8 & 5.3 & 91.4 & 3.4 & 186.2 & 6.9 \\
\hline 8 & 29 & 78.7 & 2.7 & 104.0 & 3.6 & 11.9 & 0.4 \\
\hline 9 & 33 & 99.3 & 3.0 & 66.3 & 2.0 & 165.5 & 5.0 \\
\hline 10 & 37 & 116.3 & 3.1 & 127.6 & 3.4 & 123.8 & 3.3 \\
\hline 11 & 48 & 126.6 & 2.6 & 146.0 & 3.0 & 55.3 & 1.2 \\
\hline 12 & 51 & 133.8 & 2.6 & 121.9 & 2.4 & 186.1 & 3.6 \\
\hline 13 & 36 & 129.8 & 3.6 & 105.7 & 2.9 & 205.1 & 5.7 \\
\hline 14 & 30 & 75.1 & 2.5 & 47.2 & 1.6 & 108.8 & 3.6 \\
\hline 15 & 30 & 115.8 & 3.7 & 143.0 & 4.6 & 90.8 & 2.9 \\
\hline 16 & 19 & 15.1 & 0.8 & 22.3 & 1.2 & 6.4 & 0.3 \\
\hline 17 & 28 & 92.9 & 3.3 & 128.6 & 4.6 & 69.4 & 2.5 \\
\hline 18 & 24 & 76.8 & 3.2 & 84.2 & 3.5 & 76.5 & 3.2 \\
\hline 19 & 29 & 76.5 & 2.5 & 67.3 & 2.2 & 63.3 & 2.0 \\
\hline 20 & 20 & 68.7 & 3.4 & 72.8 & 3.6 & 69.8 & 3.5 \\
\hline 21 & 31 & 106.9 & 3.4 & 161.7 & 5.2 & 121.7 & 3.9 \\
\hline 22 & 14 & 48.3 & 3.5 & 38.4 & 2.7 & 67.8 & 4.8 \\
\hline 23 & 27 & 87.4 & 3.2 & 91.1 & 3.4 & 70.8 & 2.6 \\
\hline 24 & 28 & 73.9 & 2.6 & 82.4 & 2.9 & 68.1 & 2.4 \\
\hline Total & $790 / 501^{*}$ & 2411.5 & $3.0 / 4.8^{* *}$ & 2294.8 & 2.9 & 2674.6 & 3.4 \\
\hline
\end{tabular}

LG: Linkage group; *: data is shown as number of markers mapped/unique locations; ${ }^{* *}$ : data is shown as $\mathrm{cM} / \mathrm{marker}$ and $\mathrm{cM} /$ /unique marker location. 


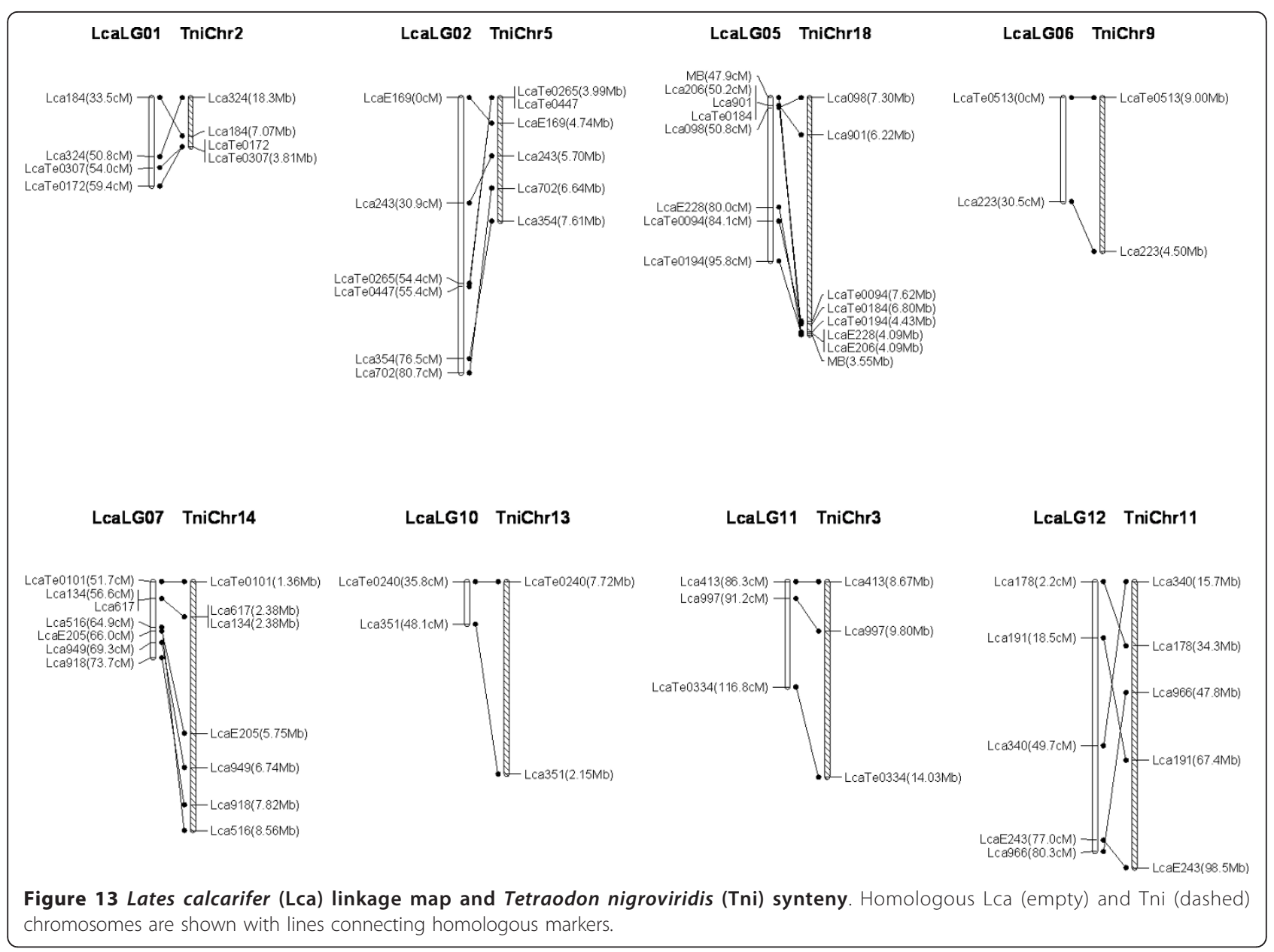

recombination rates in telomeric regions than males on LGs 1, 2, 3, 5 and 9, while recombination rates are much higher in females within regions possibly proximal to the centromere on LGs 1, 3, 9, 10, 17, 23 and 24. This is similar to linkage map of rainbow trout [8].

\section{QTL fine mapping}

To improve the utility of the QTL in MAS, and to move toward the positional cloning of candidate genes, fine mapping of the QTL to a smaller region of the chromosome is necessary [53,54]. In foodfish species, although QTL mapping has been conducted in a few species, such rainbow trout [31,55], salmon [56], Japanese flounder [30] and tilapia [29], QTL were mapped in large genomic regions, usually bigger than $10 \mathrm{cM}$. In Asian seabass, the number of available markers on our previous map [14] limited the possibility for fine mapping QTL in Asian seabass; therefore the development of additional markers in the QTL regions is an important target in this study. As compared to the previous QTL mapping results, the positions of QTL were much refined with the markers from the enhanced map
(Figure 15). The peaks of qBW2-a and BW2-b were flanked by $L c a 182$ and $L c a 287$ with distance reduced from $11.3 \mathrm{cM}$ on previous map to $6.0 \mathrm{cM}$, and closely linked to $L \mathrm{ca} 287$ with a distance of $2.0 \mathrm{cM}$. Similarly, the peaks of the other QTL (qBW2-b, c, d and e) was refined from $8.3 \mathrm{cM}$ on previous map to a small region between flanking markers, with intervals 6.1, 1.4, 0.6, 0.2 and $0.1 \mathrm{cM}$ respectively. On LG3, qBW3 was from 9.6 $\mathrm{cM}$ to $0.1 \mathrm{cM}$. The refined QTL supply a basis for identifying potential candidate genes located in these refined QTL through comparative genome analysis. Fortunately, the complete genome sequences of several mode fish species (i.e. zebrafish, medaka, freshwater pufferfish, fugu and stickleback) [57-60] are available, and the sequencing of genomes of several important foodfish species (common carp, salmon and tilapia) are in progress.

\section{Comparative genome analysis}

Methods to map sequence based markers and to compare maps with relevant model systems are crucial to extend genomic-level analysis to non-model species 


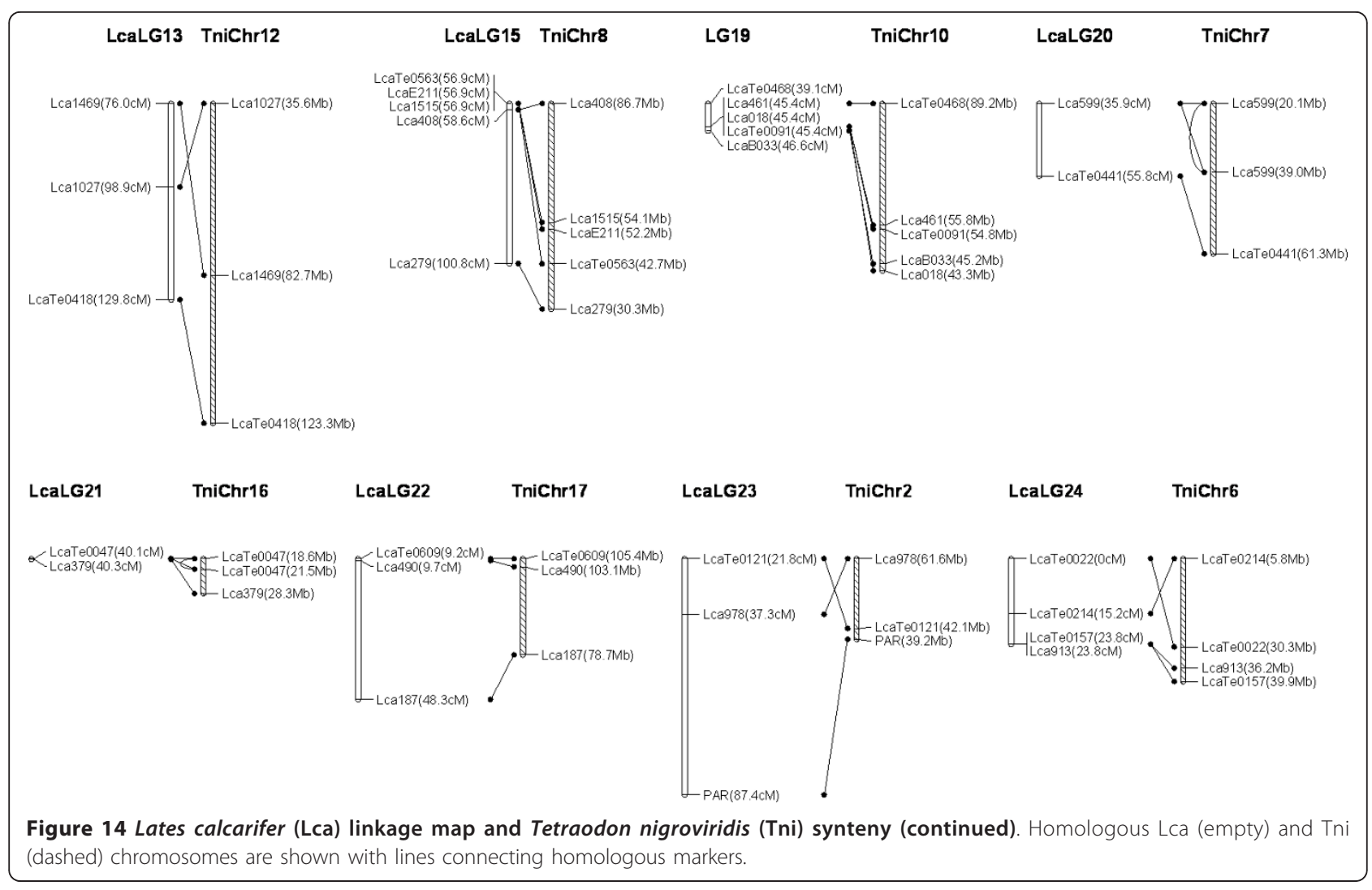

[54]. According to the phylogenetic tree including over 30 fish species, constructed using 12 mitochondrial genes in our previous study, Asian seabass is more closely related to $T$. nigroviridis than to zebrafish and medaka [61]. However, in our previous comparative mapping, no synteny block could be identified between Aisan seabass and T. nigroviridis although flanking sequences of 55 microsatellites showed high similarity to known genomic DNA sequences of $T$. nigroviridis [14]. Herein, we developed our second generation linkage map with high density and demonstrated that, 16 syteny blocks of Asian seabass were syntenic to the 16 counterparts of $T$. nigroviridis chromosomes. The result showed certain colinearity for the 16 syntenic chromosome/linkage pairs between the two foodfish species, $T$. nigroviridis and Asian seabass. The conserved syntenies identified here between the Asian seabass and T. nigroviridis should facilitate studies on genome evolution and analysis of structural genome, but more importantly should facilitate functional inference of genes in Asian seabass. It is well known that determination of gene functions is difficult in non-model species; functional genome analysis will have to rely heavily on the establishment of homologies from model species. Mapping more ESTs or gene sequences on the linkage map of Asian seabass should enhance comparative mapping, thereby transferring genome information from model species to Asian seabass.

\section{Identification of candidate genes in QTL}

Maps with sequence-based markers are useful not only for comparative genomics but also resolving mapped genomic regions to a tractable number of candidate genes, especially if there is synteny with related model species. After refining the positions of QTL, the regions of candidate genes were delimited more precisely. The LOD peaks were detected near the positions of markers Lca562, Lca371, LcaTe0359, Lca250 and Lca137 respectively, therefore we examined regions of the sequenced zebrafish and medaka genome corresponding to the QTL regions on Asian seabass, using the markers overlapped on QTL LOD peaks. Such an approach allows us to prioritize our research effort on candidate genes that are found collocating with QTL LOD peaks. Candidate gene approaches have been successfully used for identification of QTL $[62,63]$. Three putative growth-related genes, cathepsin $\mathrm{D}, K C T D 15$ and $\operatorname{csm} d 2$, were found to be positioned directly at QTL peaks between small region of 0.2-1.4 cM, making them the strongest candidate genes for growth traits. Further two-way ANOVA revealed that allelic substitution at these two genes showed significant effects on growth-related traits. 


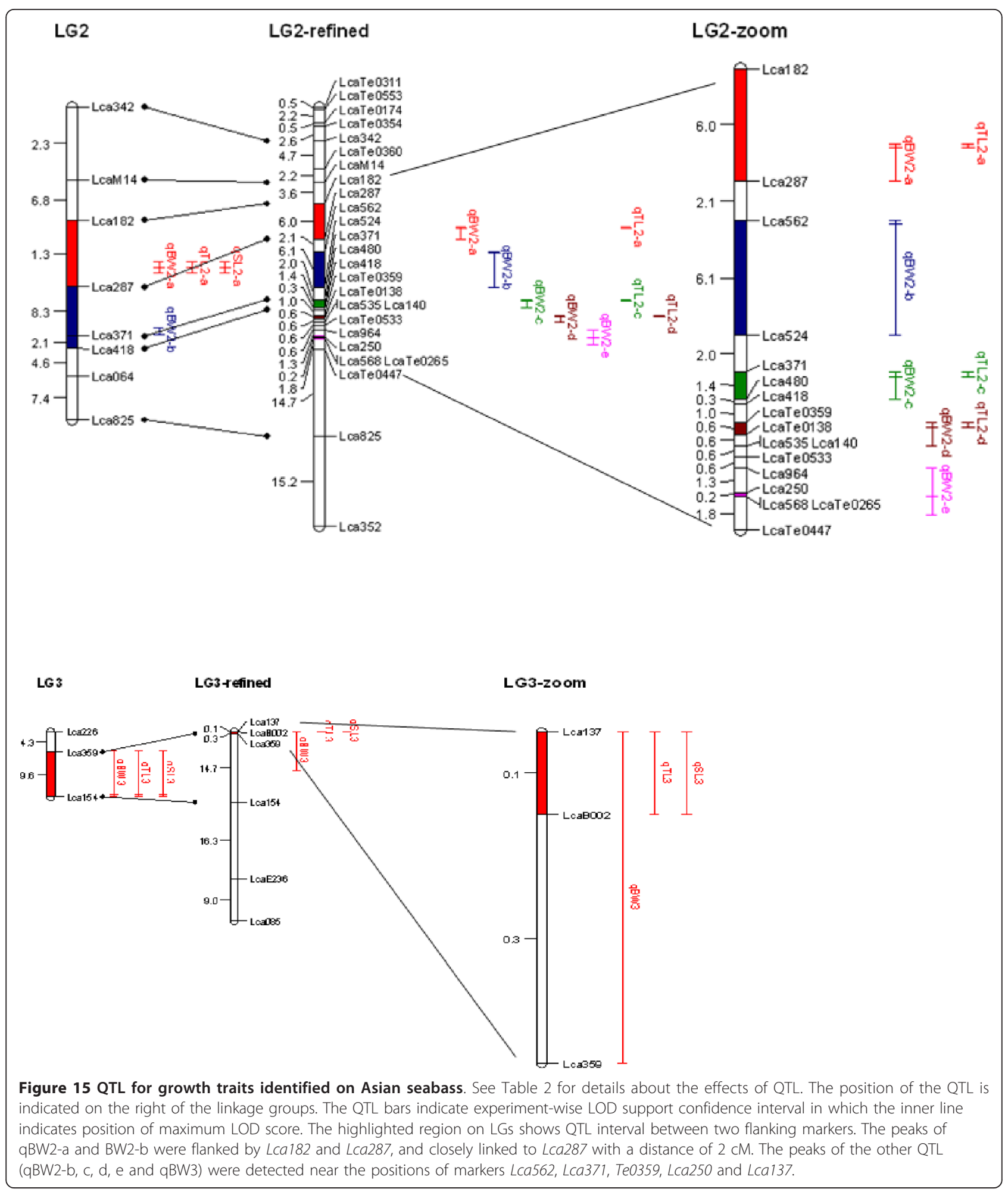

Certain allelic combinations showed significantly higher values of the growth traits. The candidate genes are rare examples of QTL fine mapping in foodfish species. Interestingly, the QTL cluster at Lca371 underlying growth traits of Asian seabass showed similarity to the cathepsin D gene of human, which is related to cancer [64] and Alzheimer's disease [65] and has become a hotspot of human genetics study. The genotypes at these genes may be useful for growth improvement through marker-assisted selection, gene cloning and functional 
Table 2 Location of QTL and magnitude of QTL effects on growth traits in Asian seabass

\begin{tabular}{|c|c|c|c|c|c|c|c|c|c|c|c|c|c|c|c|c|}
\hline \multirow[t]{2}{*}{ Trait } & \multirow[t]{2}{*}{ QTL } & \multirow[t]{2}{*}{ LG } & \multirow{2}{*}{$\begin{array}{l}\text { Position } \\
\text { (cM) }\end{array}$} & \multirow{2}{*}{$\begin{array}{l}\mathrm{Cl} \\
(\mathrm{cM})\end{array}$} & \multirow{2}{*}{$\begin{array}{l}\text { Flanking } \\
\text { markers }\end{array}$} & \multirow{2}{*}{$\begin{array}{l}\text { Interval of } \\
\text { flanking markers } \\
\text { (cM) }\end{array}$} & \multirow{2}{*}{$\begin{array}{l}\text { Nearest marker } \\
\text { and gene }\end{array}$} & \multirow{2}{*}{$\begin{array}{l}\text { Distance to the nearest } \\
\text { marker }(\mathrm{cM})\end{array}$} & \multirow[t]{2}{*}{ LOD } & \multicolumn{2}{|c|}{ LOD threshold } & \multirow{2}{*}{$\begin{array}{l}\text { PVE } \\
(\%)\end{array}$} & \multicolumn{4}{|c|}{ Phenotype means } \\
\hline & & & & & & & & & & $\begin{array}{l}\text { Experiment- } \\
\text { wise }\end{array}$ & $\begin{array}{l}\text { Linkage } \\
\text { group-wise }\end{array}$ & & $\mathrm{m} 1 \mathrm{f} 1$ & $\mathrm{~m} 1 \mathrm{f} 2$ & $\mathrm{~m} 2 \mathrm{f} 1$ & $\mathrm{~m} 2 \mathrm{f} 2$ \\
\hline \multirow[t]{6}{*}{$\begin{array}{l}\text { Body } \\
\text { weight }\end{array}$} & $\begin{array}{l}q B W 2- \\
a\end{array}$ & LG2 & 20.3 & $\begin{array}{l}20.3- \\
22.3\end{array}$ & $\begin{array}{l}\text { Lca182- } \\
\text { Lca287 }\end{array}$ & 6.0 & Lca287 & 2 & $4.9^{* *}$ & 3.6 & 3.5 & 30.2 & 26.8 & 23.6 & 39.5 & 26.9 \\
\hline & $\begin{array}{l}q B W 2- \\
b\end{array}$ & LG2 & 26.4 & $\begin{array}{l}24.4- \\
30.5\end{array}$ & $\begin{array}{l}\text { Lca562- } \\
\text { Lca524 }\end{array}$ & 6.1 & Lca562 & 0 & $4.0^{* *}$ & 3.6 & 3.5 & 5.3 & 29.3 & 25.8 & 32.9 & 28.1 \\
\hline & $\begin{array}{l}q B W 2- \\
c\end{array}$ & LG2 & 32.5 & $\begin{array}{l}32.5- \\
33.9\end{array}$ & $\begin{array}{l}\text { Lca371- } \\
\text { Lca480 }\end{array}$ & 1.4 & $\begin{array}{l}\text { Lca371 in } \\
\text { cathepsin D }\end{array}$ & 0 & $4.5^{* *}$ & 3.6 & 3.5 & 7.0 & 25.4 & 29.0 & 28.9 & 34.0 \\
\hline & $\begin{array}{l}q B W 2- \\
d\end{array}$ & LG2 & 35.2 & $\begin{array}{l}35.2- \\
36.4\end{array}$ & $\begin{array}{l}\text { LcaTe0359- } \\
\text { LcaTe0138 }\end{array}$ & 0.6 & LcaTe0359 & 0 & $4.5^{* *}$ & 3.6 & 3.5 & 5.3 & 33.0 & 28.4 & 29.1 & 25.7 \\
\hline & $e^{q B W 2-}$ & LG2 & 39.1 & $\begin{array}{l}37.6- \\
40.1\end{array}$ & $\begin{array}{l}\text { Lca250- } \\
\text { Lca568 }\end{array}$ & 0.2 & $\begin{array}{l}\text { Lca568 in } \\
\text { KCTD15; } \\
\text { LcaTe0265 in } \\
\text { csmd2 }\end{array}$ & 0 & $4.0^{* *}$ & 3.6 & 3.5 & 4.7 & 28.6 & 32.8 & 25.9 & 29.0 \\
\hline & $q B W 3$ & LG3 & 0 & $0-0.1$ & $\begin{array}{l}\text { Lca137- } \\
\text { LcaB002 }\end{array}$ & 0.1 & Lca137 & 0 & $5.3^{* *}$ & 3.6 & 2.6 & 6.3 & 31.8 & 25.1 & 32.3 & 28.0 \\
\hline \multirow[t]{4}{*}{$\begin{array}{l}\text { Total } \\
\text { length }\end{array}$} & $\begin{array}{l}\text { qTL2- } \\
a\end{array}$ & LG2 & 22.3 & $\begin{array}{l}20.3- \\
20.5\end{array}$ & $\begin{array}{l}\text { Lca182- } \\
\text { Lca287 }\end{array}$ & 6.0 & Lca287 & 2 & $5.5^{* *}$ & 5.5 & 5.5 & 53.1 & 120.1 & 105.0 & 138.0 & 130.5 \\
\hline & qTL2-C & LG2 & 32.5 & $\begin{array}{l}32.5- \\
32.7\end{array}$ & $\begin{array}{l}\text { Lca371- } \\
\text { Lca480 }\end{array}$ & 1.4 & $\begin{array}{l}\text { Lca371 in } \\
\text { catheps D }\end{array}$ & 0 & $5.5^{* *}$ & 5.5 & 5.5 & 8.6 & 116.5 & 123.3 & 123.0 & 131.0 \\
\hline & $\begin{array}{l}\text { qTL2- } \\
d\end{array}$ & LG2 & 35.2 & $\begin{array}{l}35.2- \\
35.4\end{array}$ & $\begin{array}{l}\text { LcaTe0359- } \\
\text { LcaTe0138 }\end{array}$ & 0.6 & LcaTe0359 & 0 & $5.5^{* *}$ & 5.5 & 5.5 & 6.5 & 129.6 & 121.8 & 123.2 & 117.5 \\
\hline & qTL3 & LG3 & 0 & $0-0.1$ & $\begin{array}{l}\text { Lca137- } \\
\text { LcaB002 }\end{array}$ & 0.1 & Lca137 & 0 & $5.7^{* *}$ & 5.5 & 2.3 & 6.7 & 127.2 & 116.9 & 128.2 & 121.6 \\
\hline \multirow[t]{4}{*}{$\begin{array}{l}\text { Standard } \\
\text { length }\end{array}$} & $\begin{array}{l}q S L 2- \\
a\end{array}$ & LG2 & 22.3 & $\begin{array}{l}20.3- \\
20.5\end{array}$ & $\begin{array}{l}\text { Lca182- } \\
\text { Lca287 }\end{array}$ & 6.0 & Lca287 & 2 & 5.1 & 5.4 & 5.3 & 53.8 & 98.7 & 86.7 & 114.2 & 108.1 \\
\hline & $q S L 2-c$ & LG2 & 32.5 & $\begin{array}{l}32.5- \\
32.7\end{array}$ & $\begin{array}{l}\text { Lca371- } \\
\text { Lca480 }\end{array}$ & 1.4 & $\begin{array}{l}\text { Lca371 in } \\
\text { catheps D }\end{array}$ & 0 & 5.0 & 5.4 & 5.3 & 7.9 & 96.6 & 101.8 & 101.5 & 108.1 \\
\hline & $\begin{array}{l}q S L 2- \\
d\end{array}$ & LG2 & 35.2 & $\begin{array}{l}35.2- \\
35.4\end{array}$ & $\begin{array}{l}\text { LcaTe0359- } \\
\text { LcaTe0138 }\end{array}$ & 0.6 & LcaTe0359 & 0 & $5.3^{*}$ & 5.4 & 5.3 & 6.2 & 107.1 & 100.6 & 101.8 & 97.3 \\
\hline & qSL3 & LG3 & 0 & $0-0.1$ & $\begin{array}{l}\text { Lca137- } \\
\text { LcaB002 }\end{array}$ & 0.1 & Lca137 & 0 & $5.7^{* *}$ & 5.4 & 2.5 & 6.7 & 105.2 & 96.5 & 106.0 & 100.4 \\
\hline
\end{tabular}

For each QTL detected, the confidence interval (CI), linkage group maximum LOD score, and percentage of the phenotypic variance explained (PVE) are indicated. The experiment-wise LOD significance thresholds are 4.5 for body weight, and 6.1 for total length and body length. Mean phenotypic values of each trait were also calculated for those progeny with the alternate alleles at the most closely linked microsatellite markers, inherited from the male parent ( $\mathrm{m} 1$ or $\mathrm{m} 2$ ), alleles from the female parent (f1 or f2). **: Experiment-wise significant $\mathrm{QTL}$; * Linkage-group-wise significant $\mathrm{QTL}$. 

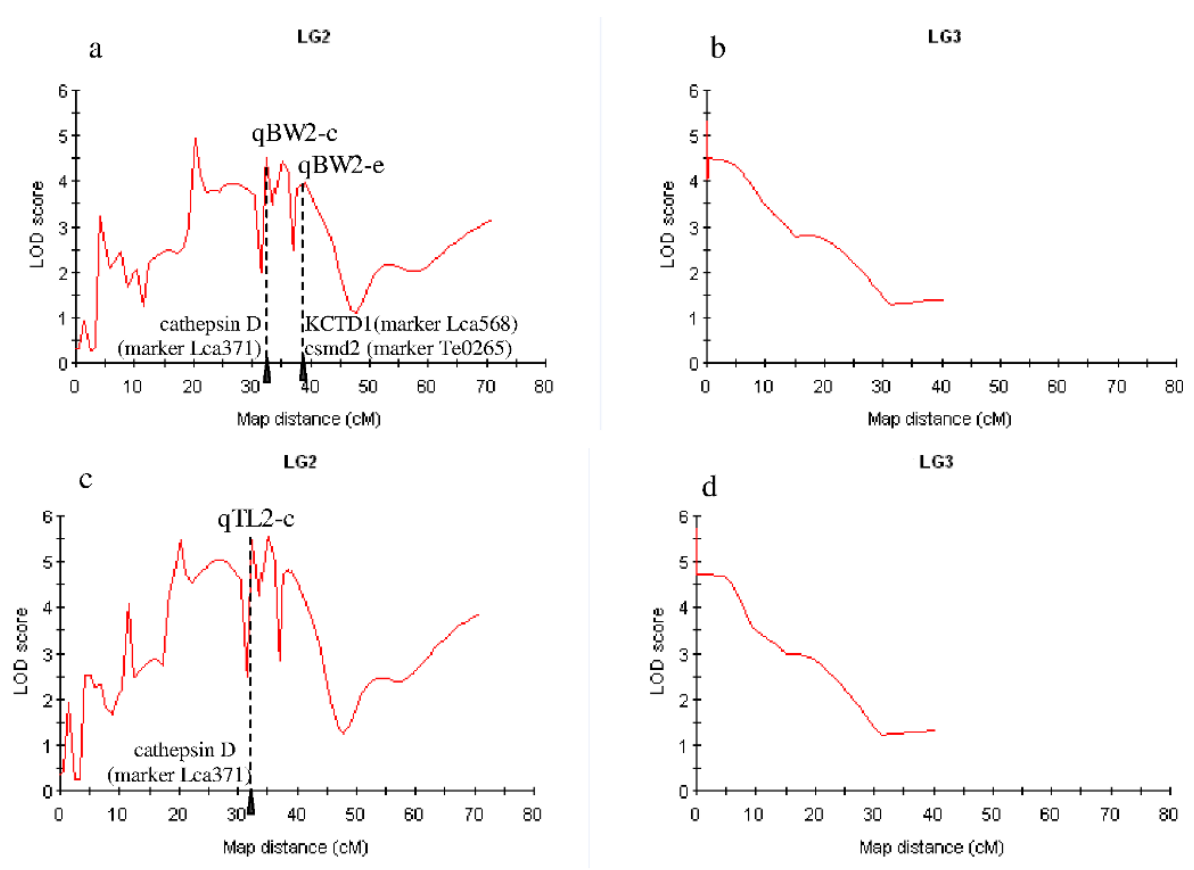

$\mathrm{e}$

LG2

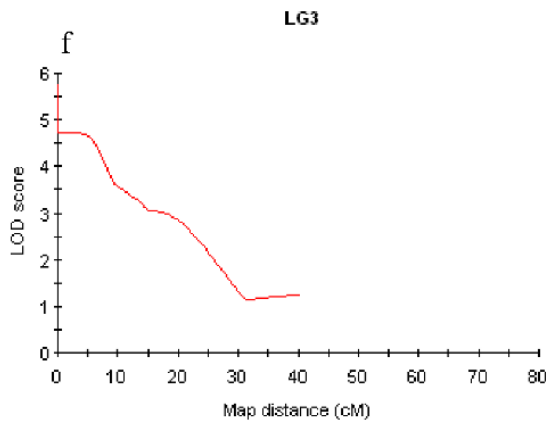

Figure 16 Mapping of QTL for growth traits. a, QTL for body weight on LG2; b, QTL for body weight on LG3; c, QTL for total length on LG2; d, QTL for total length on LG3; e, QTL for standard length on LG2; f, QTL for standard length on LG3. The lines were drawn by plotting the LOD scores at each marker as well as at $1.0 \mathrm{cM}$ intervals along the linkage group. The arrow shows the position of genes and their markers where overlapped with QTL peaks.

analysis. In humans, KCTD15 may be associated with obesity [66], while $c s m d 2$ may be an oligodendroglioma suppressor [67]. Therefore it is interesting to further study the mechanisms underlying the associations between polymorphisms in these two genes with growth traits in Asian seabass.

\section{Conclusions}

We constructed a second generation genetic linkage map and carried out comparative mapping of synteny between Asian seabass and T. nigroviridis. Moreover, we applied this map for refinement of QTL for growth traits using extensive progeny testing with defined recombination within the QTL region. We estimated their locations within short intervals, identified potential candidate genes, and further defined the phenotypic consequences of alternative candidate gene alleles. This second generation linkage map should facilitate the advancement of genetic studies for a wide variety of complex traits in foodfish species. In the future, more SNP markers should be identified by using next generation sequencing [68] to enable whole genome association studies [69] to facilitate genomic selection [70] and to understand the genetic basis of phenotypic variation of important traits [71,72].

\section{Methods}

Reference families for linkage mapping and QTL analysis The reference families used for the construction of the first generation linkage map [14] were used for the construction of the second generation linkage map. Briefly, a whole broodstock containing 94 brooders, including 

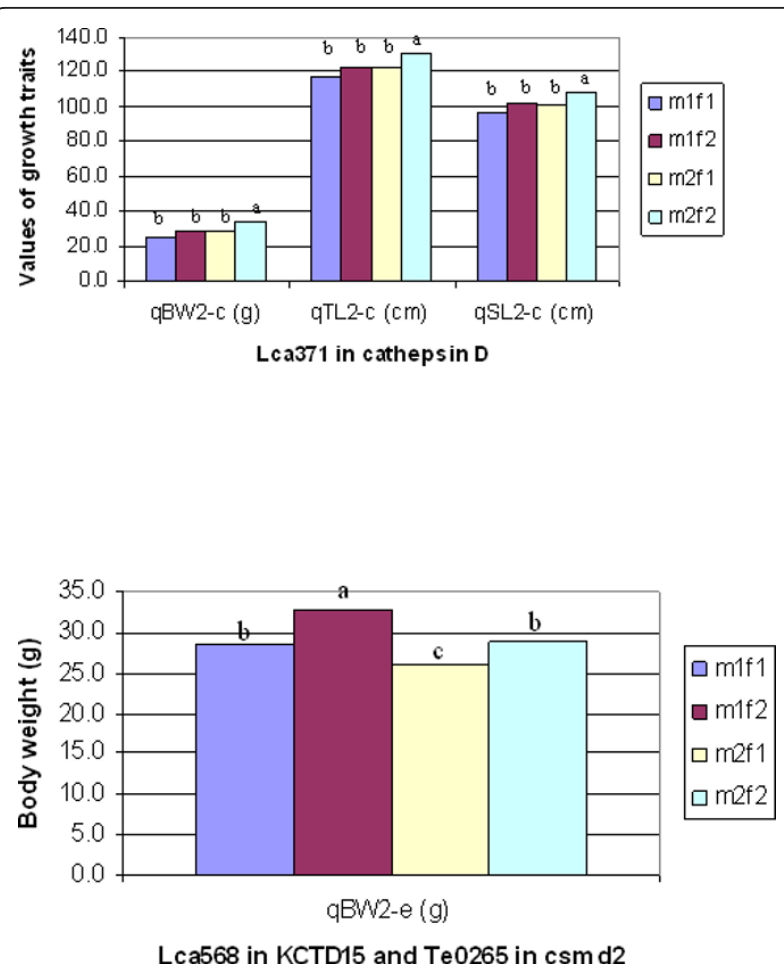

Figure 17 The effects of genotypes of cathepsin D (left), KCTD15 and csmd2 (right). The letters on the top of bars indicate the level of difference in phenotypic value between genotypes. The same letter indicates that the difference is statistically insignificant, whereas different letters represent statistically significant (Bonferroni T tests at $\alpha<0.01$ ) difference.

48 males and 46 females collected from the wild in Southeast Asia four years ago, were genotyped with nine polymorphic microsatellites as described previously $[14,41]$. One female and two male brooders were selected for constructing a mapping panel because of their high allelic diversity and genetic differences. By crossing the female and two male brooders, millions of eggs were produced. A total of 47 and 46 full-sib progeny were randomly collected from the two full-sib families, respectively. The reference family including one parental pair and 380 offspring used for preliminary QTL analysis for growth traits was used in the fine mapping of QTL for growth traits.

Fin clips of the parents were collected and kept in absolute ethanol, whereas the whole body of each offspring at the age of 90 days post hatch (dph) was cut into small pieces, soaked in absolute ethanol, and kept in a $-80^{\circ}$ freezer. DNA was isolated and arrayed into 96well PCR plates as described preciously [14].

\section{Identification and genotyping of DNA markers}

Partial genomic DNA libraries enriched for CA-, GA-, CAA-, GACA- and GATA- repeats were constructed as described previously [73]. Repeat-enriched DNA fragments of 400-1200 bp in length were cloned into pGEM-T vector (Promega, San Luis Obispo, CA), and transformed into XL-10 blue supercompetent cells (Stratagene, La Jolla, CA). The libraries were arrayed into 96well plates for bidirectional sequencing on an ABI3730xl DNA sequencer (ABI, Foster City, CA) using the BigDye V3.0 kit and M13 and M13 reverse primers. Redundant and overlapping sequences were grouped using Sequencher (Gene Codes, Ann Arbor, MI). Unique sequences were compared to known microsatellite sequences of Asian seabass prior to primer design to remove redundancy. Microsatellites in ESTs were isolated using a method described previously [74]. Sequences containing $\mathrm{CA}>7, \mathrm{GA}>7, \mathrm{CAA}>6, \mathrm{GACA}>5$ and GATA $>5$ were subjected to primer design using PrimerSelect (DNASTAR, Brighton, MA), targeting a product size between 100 and $400 \mathrm{bp}$. Primers were designed for each unique sequence using PrimerSelect (DNASTAR, Madison, WI). One primer of each pair was labeled with FAM or HEX fluorescent dyes at the 5 '-end. PCR for genotyping was carried out as described previously [14]. Products were analyzed using the DNA sequencer ABI3730xl, and genotyping was carried out to determine fragment size against the size standard GSROX-500 (Applied Biosystems, Foster City, CA) with software GeneMapper V3.5 (Applied Biosystems).

SNPs in genes were detected by PCR amplification of DNA of three parents and sequencing of PCR products. Briefly, genes of Asian seabass were aligned with genomic sequence data from zebrafish on GenBank. Primer sites in conserved exon regions were identified and primer pairs allowing PCR amplification of an intron-spanning fragment were developed. Amplified intronspanning fragments which were sequenced as described above to detect SNP in the three parents from the reference families for linkage mapping. Ten SNPs were detected in 9 genes (Additional file 1). The genotyping for the 10 polymorphic SNP markers were performed by direct sequencing PCR products using ABI 3730xl Genetic Analyzer (Applied Biosystems). SNP genotypes were scored using Sequencher 4.9 (Genecodes).

\section{Linkage Analysis}

CRIMAP 2.4 software [75] was used for linkage analysis. Markers were placed into linkage groups based on twopoint LOD scores (>3.0) with markers from the previous map. Ordering the markers within a linkage group began with the previous map. A new marker was inserted into the map by evaluating the LOD at every possible location. The marker was then inserted at the location with the best LOD, and the change in length of the linkage group was evaluated. If a switched pair improved the LOD, the pair was switched and the 
process repeated until no better LOD could be found. The process of switching the order of marker pairs was repeated to finalize marker order. The final maps represent the most likely marker order identified with the complete data set. Once the most likely order had been derived, sex-average and sex-specific linkage distances were estimated for each using the Kosambi function. MapChart 2.2 software was used for graphical visualization of the linkage groups [76]. The total length of the linkage map was calculated by summing up the length of all 24 linkage groups.

\section{Comparative genome analysis}

As our previous study showed that Asian seabass is more closely related to $T$. nigroviridis than to zebrafish and medaka [61], comparison of flanking sequences of each Asian seabass marker on the map with the assembled genomic DNA sequences of the T. nigroviridis was conducted using BLAT http://www.genoscope.cns.fr/blatserver/cgi-bin/tetraodon/webBlat. BLAT searching was performed with a score above 80 and an alignment length of more than $50 \mathrm{bp}$ as recommended [77].

\section{QTL fine mapping}

In our previous studies $[39,47]$, we identified significant QTL for growth traits on LGs (linkage groups) 2 and 3. To map the QTL on LGs 2 and 3 with more precision, 33 additional microsatellites located near the QTL on these two linkage groups were genotyped. With genotype data of the markers on the QTL regions and phenotypic data of the 380 progeny, QTL analysis was carried out using the program MapQTL 5.0 [78]. Interval mapping and multiple QTL model (MQM) mapping were utilized to detect any significant association between growthrelated traits and marker loci in the data sets. Cofactors for MQM analyses were automatically selected with a pvalue of 0.02 . The LOD score significance thresholds were calculated by permutation tests in MapQTL 5.0, with a experiment-wise significance level of $\alpha<0.05, \mathrm{n}=$ 1000 for significant linkages. Calculation of the percentage of phenotypic variance explained (PVE) by a QTL was performed in MapQTL 5 on the basis of the population variance found within the progeny of the cross.

\section{Potential candidate genes and their effects on growth traits}

For those microsatellites, positions of which were detected well-overlapping with QTL peaks, we did a blast search of the sequences of microsatellites to identify potential candidate genes in these loci. Blast searches were done against the whole genome sequences of zebrafish and medaka in the current ENSEMBL release version http://www.ensembl.org and against all known sequences in GenBank.
A two-way ANOVA was performed on the 380 progeny using four allelic combinations $(\mathrm{m} 1 \mathrm{f} 1, \mathrm{~m} 1 \mathrm{f} 2, \mathrm{~m} 2 \mathrm{f} 1$ and $\mathrm{m} 2 \mathrm{f} 2$ ) from markers in the three candidate genes in order to investigate associations between phenotypic traits and genotypes of these genes. Mean phenotypic values of each trait were calculated for those progeny with the alternate alleles of the microsatellite markers, inherited from the male parent ( $\mathrm{m} 1$ or $\mathrm{m} 2$ ), alleles inherited from the female parent (f1 or f2). This was conducted by using the general linear model (GLM) procedure of SAS (SAS Institute) and the Bonferroni method of multiple comparisons with $\alpha<0.01$.

\section{Additional material}

Additional file 1: 790 DNA markers mapped to the second generation linkage map of Asian seabass.

Additional file 2: Comparative mapping of markers of Lates calcarifer through BLAT search against Tetraodon nigroviridis genome.

\section{Abbreviations}

QTL: Quantitative trait loci; SNP: Single nucleotide polymorphism; cM: Centimorgan; RAPD: Rapid amplified polymorphic DNA; AFLP: Amplified fragment length polymorphism.

\section{Acknowledgements}

This study is funded by Ministry of National Development for the project "To ensure self-sufficiency of safe seafood for Singapore through the development of aquaculture genomic tools for marker-assisted selective breeding of tropical marine foodfish". We thank staffs of Marine Aquaculture Center, AVA for technical supports.

\section{Authors' contributions}

GHY initiated and overviewed the Asian seabass project and finalized the manuscript. WCM and YGH designed the study. WCM, BZY, HXP, XJH, SF, LLC, FF and ZZY conducted the experiments. WCM conducted the data analysis and wrote the manuscript. All authors have read and approved the final manuscript.

Received: 15 December 2010 Accepted: 2 April 2011

Published: 2 April 2011

\section{References}

1. Falconer DS, Mackay TFC: Introduction to Quantitative Genetics. Harlow, Essex, UK: Addison Wesley Longman; Fourth 1996.

2. Paterson AH, DeVerna JW, Lanini B, Tanksley SD: Fine mapping of quantitative trait loci using selected overlapping recombinant chromosomes, in an interspecies cross of tomato. Genetics 1990, 124(3):735-742.

3. Varshney RK, Tuberosa R, (eds): Genomics-Assisted Crop ImprovementVol 2: Genomics Applications in Crops. Netherlands: Springer; 2007.

4. Lander ES, Green P, Abrahamson J, Barlow A, Daly MJ, Lincoln SE, Newburg L: MAPMAKER: An interactive computer package for constructing primary genetic linkage maps of experimental and natural populations. Genomics 1987, 1:174-181.

5. Tautz D: Hypervariabflity of simple sequences as a general source for polymorphic DNA markers. Nucl Acids Res 1989, 17(16):6463.

6. Liu ZJ, Cordes JF: DNA marker technologies and their applications in aquaculture genetics. Aquaculture 2004, 238(1-4):1-37.

7. Gilbey J, Verspoor E, McLay A, Houlihan D: A microsatellite linkage map for Atlantic salmon (Salmo salar). Anim Genet 2004, 35(2):98-105. 
8. Sakamoto T, Danzmann RG, Gharbi K, Howard P, Ozaki A, Khoo SK, Woram RA, Okamoto N, Ferguson MM, Holm LE, et al: A microsatellite linkage map of rainbow trout (Oncorhynchus mykiss) characterized by large sex-specific differences in recombination rates. Genetics 2000, 155(3):1331-1345.

9. Guyomard R, Mauger S, Tabet-Canale K, Martineau S, Genet C, Krieg F, Quillet E: A type I and type II microsatellite linkage map of rainbow trout (Oncorhynchus mykiss) with presumptive coverage of all chromosome arms. BMC Genomics 2006, 7:302.

10. Kucuktas H, Wang S, Li P, He C, Xu P, Sha Z, Liu H, Jiang Y, Baoprasertkul P, Somridhivej $B$, et al: Construction of genetic linkage maps and comparative genome analysis of catfish using gene-associated markers. Genetics 2009, 181(4):1649-1660.

11. Lee BY, Lee WJ, Streelman JT, Carleton KL, Howe AE, Hulata G, Slettan A Stern JE, Terai $Y$, Kocher TD: A second-generation genetic linkage map of tilapia (Oreochromis spp.). Genetics 2005, 170(1):237-244

12. Xia JH, Feng L, Zhu ZY, Fu JJ, Feng JB, Li JL, Yue GH: A consensus linkage map of the grass carp (Ctenopharyngodon idella) based on microsatellites and SNPs. BMC Genomics 2010, 11.

13. Sun $X$, Liang $L$ : A genetic linkage map of common carp (Cyprinus carpio L.) and mapping of a locus associated with cold tolerance. Aquaculture 2004, 238(1-4):165-172

14. Wang CM, Zhu ZY, Lo LC, Feng F, Lin G, Yang WT, Li J, Yue GH: A microsatellite linkage map of Barramundi, Lates calcarifer. Genetics 2007 175(2):907-915.

15. Chistiakov DA, Hellemans B, Haley CS, Law AS, Tsigenopoulos CS, Kotoulas G, Bertotto D, Libertini A, Volckaert FAM: A microsatellite linkage map of the European sea bass Dicentrarchus labrax L. Genetics 2005, 170(4):1821-1826.

16. Coimbra MRM, Kobayashi K, Koretsugu S, Hasegawa O, Ohara E, Ozaki A, Sakamoto T, Naruse K, Okamoto N: A genetic linkage map of the Japanese flounder, Paralichthys olivaceus. Aquaculture 2003, 220(14):203-218.

17. Franch $\mathrm{R}$, Louro $B$, Tsalavouta $\mathrm{M}$, Chatziplis D, Tsigenopoulos CS, Sarropoulou E, Antonello J, Magoulas A, Mylonas CC, Babbucci M: A genetic linkage map of the hermaphrodite teleost fish Sparus aurata $\mathrm{L}$. Genetics 2006, 174(2):851

18. Senger F, Priat C, Hitte C, Sarropoulou E, Franch R, Geisler R, Bargelloni L, Power D, Galibert F: The first radiation hybrid map of a perch-like fish: the gilthead seabream (Sparus aurata L). Genomics 2006, 87(6):793-800.

19. Sarropoulou E, Nousdili D, Magoulas A, Kotoulas G: Linking the genomes of nonmodel teleosts through comparative genomics. Mar Biotechnol 2008, 10(3):227-233.

20. Shimoda N, Knapik EW, Ziniti J, Sim C, Yamada E, Kaplan S, Jackson D, de Sauvage $F$, Jacob H, Fishman MC: Zebrafish genetic map with 2000 microsatellite markers. Genomics 1999, 58(3):219-232.

21. Groenen MA, Wahlberg $P$, Foglio $M$, Cheng $H H$, Megens $H J$, Crooijmans RP, Besnier F, Lathrop M, Muir WM, Wong GK, et al: A high-density SNP-based linkage map of the chicken genome reveals sequence features correlated with recombination rate. Genome Res 2009, 19(3):510-519.

22. Ihara N, Takasuga A, Mizoshita K, Takeda H, Sugimoto M, Mizoguchi Y, Hirano T, Itoh T, Watanabe T, Reed K: A comprehensive genetic map of the cattle genome based on 3802 microsatellites. Genome Research 2004, 14(10a):1987.

23. Arias JA, Keehan M, Fisher P, Coppieters W, Spelman R: A high density linkage map of the bovine genome. BMC Genet 2009, 10:18.

24. Vingborg RK, Gregersen VR, Zhan B, Panitz F, Hoj A, Sorensen KK, Madsen LB, Larsen $K$, Hornshoj $H$, Wang $X$, et al: A robust linkage map of the porcine autosomes based on gene-associated SNPs. BMC Genomics 2009, 10:134.

25. Hwang TY, Sayama T, Takahashi M, Takada Y, Nakamoto Y, Funatsuki H, Hisano H, Sasamoto S, Sato S, Tabata S, et al: High-density integrated linkage map based on SSR markers in soybean. DNA Res 2009, 16(4):213-225.

26. Sato K, Nankaku N, Takeda K: A high-density transcript linkage map of barley derived from a single population. Heredity 2009, 103(2):110-117.

27. Troggio M, Malacarne G, Coppola G, Segala C, Cartwright DA, Pindo M, Stefanini M, Mank R, Moroldo M, Morgante $M$, et al: A dense singlenucleotide polymorphism-based genetic linkage map of grapevine (Vitis vinifera L.) anchoring Pinot Noir bacterial artificial chromosome contigs. Genetics 2007, 176(4):2637-2650.
28. Reid D, Szanto A, Glebe B, Danzmann R, Ferguson M: QTL for body weight and condition factor in Atlantic salmon (Salmo salar): comparative analysis with rainbow trout (Oncorhynchus mykiss) and Arctic charr (Salvelinus alpinus). Heredity 2004, 94(2):166-172

29. Cnaani A, Hallerman EM, Ron M, Weller Jl, Indelman M, Kashi Y, Gall GAE, Hulata G: Detection of a chromosomal region with two quantitative trait loci, affecting cold tolerance and fish size, in an F-2 tilapia hybrid. Aquaculture 2003, 223(1-4):117-128.

30. Fuji K, Kobayashi K, Hasegawa O, Coimbra M, Sakamoto T, Okamoto N: Identification of a single major genetic locus controlling the resistance to lymphocystis disease in Japanese flounder (Paralichthys olivaceus). Aquaculture 2006, 254(1-4):203-210.

31. Ozaki A, Sakamoto T, Khoo S, Nakamura K, Coimbra M, Akutsu T, Okamoto N: Quantitative trait loci (QTLs) associated with resistance/ susceptibility to infectious pancreatic necrosis virus (IPNV) in rainbow trout (Oncorhynchus mykiss). Mol Genet Genom 2001, 265(1):23-31.

32. Massault C, Hellemans B, Louro B, Batargias C, Van Houdt JKJ, Canario A, Volckaert FAM, Bovenhuis $\mathrm{H}$, Haley C, De Koning DJ: QTL for body weight, morphometric traits and stress response in European sea bass Dicentrarchus labrax. Anim Genet 2010, 41:337-345.

33. Wang S, Zhang L, Meyer E, Matz MV: Construction of a high-resolution genetic linkage map and comparative genome analysis for the reefbuilding coral Acropora millepora. Genom Biol 2009, 10(11):R126.

34. Criscione CD, Valentim CL, Hirai H, Loverde PT, Anderson TJ: Genomic linkage map of the human blood fluke Schistosoma mansoni. Genom Biol 2009, 10(6):R71.

35. Yamamoto K, Nohata J, Kadono-Okuda K, Narukawa J, Sasanuma M, Sasanuma S, Minami H, Shimomura M, Suetsugu Y, Banno Y, et al: A BACbased integrated linkage map of the silkworm Bombyx mori. Genom Biol 2008, 9(1):R21

36. Gross JB, Protas M, Conrad M, Scheid PE, Vidal O, Jeffery WR, Borowsky R, Tabin CJ: Synteny and candidate gene prediction using an anchored linkage map of Astyanax mexicanus. Proc Natl Acad Sci USA 2008, 105(51):20106-20111.

37. Hillier LW, Miller RD, Baird SE, Chinwalla A, Fulton LA, Koboldt DC, Waterston $\mathrm{RH}$ : Comparison of $\mathrm{C}$. elegans and C. briggsae genome sequences reveals extensive conservation of chromosome organization and synteny. PLoS Biol 2007, 5(7):e167.

38. FAO: Food and Agriculture Organization of the United Nations Statistics. 2008.

39. Wang CM, Lo LC, Zhu ZY, Yue GH: A genome scan for quantitative trait loci affecting growth-related traits in an F1 family of Asian seabass (Lates calcarifer). BMC Genomics 2006, 7:274

40. Yue GH, Li Y, Chao TM, Chou R, Orban L: Novel microsatellites from Asian seabass (Lates calcarifer) and their application to broodstock analysis. Mar Biotechnol 2002, 4(5):503-511.

41. Zhu ZY, Lin G, LC Lo, YX Xu, Renee C, et al: Genetic analyses of Asian seabass stocks using novel polymorphic microsatellites. Aquaculture 2006, 256:167-173.

42. Zhu ZY, Wang CM, Lo LC, Feng F, Lin G, Yue GH: Isolation, characterization, and linkage analyses of 74 novel microsatellites in Barramundi (Lates calcarifer). Genome 2006, 49(8):969-976.

43. Xu YX, Zhu ZY, Lo LC, Wang CM, Lin G, Feng F, Yue GH: Characterization of two parvalbumin genes and their association with growth traits in Asian seabass (Lates calcarifer). Anim Genet 2006, 37:266-268.

44. Xia JH, He XP, Bai ZY, Yue GH: Identification and characterization of 63 microRNAs in the Asian seabass Lates calcarifer. Plos ONE 2011, 6:e17537.

45. Wang CM, Lo LC, Feng F, Gong P, Li J, Zhu ZY, Lin G, Yue GH: Construction of a BAC library and mapping BAC clones to the linkage map of Barramundi, Lates calcarifer. BMC Genomics 2008, 9:139.

46. Xia JH, Yue $\mathrm{GH}$ : Identification and analysis of immune-related transcriptome in Asian seabass Lates calcarifer. BMC Genomics 2010, 11:356.

47. Wang C, Lo L, Feng F, Zhu Z, Yue G: Identification and verification of QTL associated with growth traits in two genetic backgrounds of Barramundi (Lates calcarifer). Anim Genet 2008, 39(1):34-39.

48. Harushima $Y$, Yano M, Shomura A, Sato M, Shimano T, Kuboki $Y$, Yamamoto T, Lin SY, Antonio BA, Parco A, et al: A high-density rice genetic linkage map with 2275 markers using a single F2 population. Genetics 1998, 148(1):479-494. 
49. Jensen-Seaman MI, Furey TS, Payseur BA, Lu Y, Roskin KM, Chen CF, Thomas MA, Haussler D, Jacob HJ: Comparative recombination rates in the rat, mouse, and human genomes. Genome Res 2004, 14(4):528-538

50. Hardie DC, Hebert PDN: Genome-size evolution in fishes. Can J Fish Aqua Sci 2004, 61:1636-1646.

51. Woram RA, McGowan C, Stout JA, Gharbi K, Ferguson MM, Hoyheim B, Davidson EA, Davidson WS, Rexroad C, Danzmann RG: A genetic linkage map for Arctic char (Salvelinus alpinus): evidence for higher recombination rates and segregation distortion in hybrid versus pure strain mapping parents. Genome 2004, 47(2):304-315.

52. Dib C, Faure S, Fizames C, Samson D, Drouot N, Vignal A, Millasseau P, Marc S, Hazan J, Seboun E, et al: A comprehensive genetic map of the human genome based on 5,264 microsatellites. Nature 1996, 380(6570):152-154

53. Mott R, Talbot C, Turri M, Collins A, Flint J: A method for fine mapping quantitative trait loci in outbred animal stocks. Proc Natl Acad Sci USA 2000, 97(23):12649.

54. Liu ZJ, (ed): Aquaculture Genome Technologies. Wiley-Blackwell; 2007.

55. Haidle L, Janssen JE, Gharbi K, Moghadam HK, Ferguson MM, Danzmann RG: Determination of quantitative trait loci (QTL) for early maturation in rainbow trout (Oncorhynchus mykiss). Mar Biotechnol 2008, 10(5):579-592.

56. Moen T, Baranski M, Sonesson AK, Kjoglum S: Confirmation and finemapping of a major QTL for resistance to infectious pancreatic necrosis in Atlantic salmon (Salmo salar): population-level associations between markers and trait. BMC Genomics 2009, 10:368.

57. Aparicio S, Chapman J, Stupka E, Putnam N, Chia J, Dehal P, Christoffels A, Rash S, Hoon S, Smit A: Whole-genome shotgun assembly and analysis of the genome of Fugu rubripes. Science 2002, 297(5585):1301.

58. Kitano J, Ross J, Mori S, Kume M, Jones F, Chan Y, Absher D, Grimwood J, Schmutz J, Myers R: A role for a neo-sex chromosome in stickleback speciation. Nature 2009, 461(7267):1079-1083.

59. Jaillon O, Aury J, Brunet F, Petit J, Stange-Thomann N, Mauceli E, Bouneau L, Fischer C, Ozouf-Costaz C, Bernot A: Genome duplication in the teleost fish Tetraodon nigroviridis reveals the early vertebrate protokaryotype. Nature 2004, 431(7011):946-957.

60. Kasahara M, Naruse K, Sasaki S, Nakatani Y, Qu W, Ahsan B, Yamada T, Nagayasu $Y$, Doi $K$, Kasai $Y$ : The medaka draft genome and insights into vertebrate genome evolution. Nature 2007, 447(7145):714-719.

61. Lin G, Lo LC, Zhu ZY, Feng F, Chou R, Yue GH: The complete mitochondrial genome sequence and characterization of singlenucleotide polymorphisms in the control region of the Asian seabass (Lates calcarifer). Mar Biotechnol 2006, 8(1):71-79.

62. Rothschild M, Jacobson C, Vaske D, Tuggle C, Wang L, Short T, Eckardt G, Sasaki S, Vincent A, McLaren D, et al: The estrogen receptor locus is associated with a major gene influencing litter size in pigs. Proc Natl Acad Sci USA 1996, 93(1):201-205.

63. Doust AN, Devos KM, Gadberry MD, Gale MD, Kellogg EA: Genetic control of branching in foxtail millet. Proc Natl Acad Sci USA 2004, 101(24):9045-9050.

64. Albayrak Ö, Tirniceriu A, Riemenschneider M, Kurz A, Scherag A, Egensperger R: The Cathepsin D (224C/T) polymorphism confers an increased risk to develop Alzheimer's disease in men. J Geront: Series A 2010, 65(3):219.

65. Kontorovich T, Levy A, Korostishevsky M, Nir U, Friedman E: Single nucleotide polymorphisms in miRNA binding sites and miRNA genes as breast/ovarian cancer risk modifiers in Jewish high-risk women. Inter J Cancer 2009, 127(3):589-597.

66. Strausberg RL, Feingold EA, Grouse LH, Derge JG, Klausner RD, Collins FS, Wagner L, Shenmen CM, Schuler GD, Altschul SF, et al: Generation and initial analysis of more than 15,000 full-length human and mouse cDNA sequences. Proc Natl Acad Sci USA 2002, 99(26):16899-16903.

67. Lau WL, Scholnick SB: Identification of two new members of the CSMD gene family. Genomics 2003, 82(3):412-415.

68. Schuster SC: Next-generation sequencing transforms today's biology. Nature 2007, 200:8.

69. Carlson CS, Eberle MA, Kruglyak L, Nickerson DA: Mapping complex disease loci in whole-genome association studies. Nature 2004, 429(6990):446-452

70. Goddard M, Hayes B: Genomic selection. J Anim Breed Genet 2007, 124(6):323-330.
71. Lazzaro BP, Sceurman BK, Clark AG: Genetic basis of natural variation in $D$. melanogaster antibacterial immunity. Science 2004, 303(5665):1873.

72. Barton NH, Keightley PD: Understanding quantitative genetic variation. Nat Review Genet 2002, 3(1):11-21.

73. Yue $\mathrm{GH}$, Chen F, Orban L: Rapid isolation and characterization of microsatellites from the genome of Asian arowana (Scleropages formosus, Osteoglossidae, Pisces). Mol Ecol 2000, 9(7):1007-1009.

74. Yue GH, Zhu ZY, Wang CM, Xia JH: A simple and efficient method for isolating polymorphic microsatellites from cDNA. BMC Genomics 2009, 10:125.

75. Green P, Falls K, Crooks S: Documentation for CRI-MAP version 2.4 Washington University School of Medicine St. Louis, Mo., USA; 1990

76. Voorrips RE: MapChart: software for the graphical presentation of linkage maps and QTLs. J Hered 2002, 93(1):77-78.

77. Kent WJ: BLAT-the BLAST-like alignment tool. Genom Res 2002, 12(4):656.

78. Van Ooijen JW: MapQTL 5, Software for the Mapping of Quantitative Trait Loci in Experimental Populations. Kyazma B.V., Wageningen, The Netherlands; 2004.

doi:10.1186/1471-2164-12-174

Cite this article as: Wang et al: A high-resolution linkage map for comparative genome analysis and QTL fine mapping in Asian seabass, Lates calcarifer. BMC Genomics 2011 12:174

\section{Submit your next manuscript to BioMed Central and take full advantage of:}

- Convenient online submission

- Thorough peer review

- No space constraints or color figure charges

- Immediate publication on acceptance

- Inclusion in PubMed, CAS, Scopus and Google Scholar

- Research which is freely available for redistribution

Submit your manuscript at www.biomedcentral.com/submit
C) Biomed Central 